Article

\title{
Baseline Conditions and Projected Future Hydro-Climatic Change in National Parks in the Conterminous United States
}

\author{
William Battaglin $1, *\left(\mathbb{D}\right.$, Lauren Hay ${ }^{2}$, David J. Lawrence $\left.{ }^{3}{ }^{(}\right)$, Greg McCabe ${ }^{4}$ and Parker Norton ${ }^{5}$ \\ 1 U.S. Geological Survey Colorado Water Science Center, Denver, CO 80225, USA \\ 2 Private Consultant; laurenhayh2o@gmail.com \\ 3 Climate Change Response Program, National Park Service, Fort Collins, CO 80525, USA; \\ david_james_lawrence@nps.gov \\ 4 U.S. Geological Survey Water Mission Area, Integrated Modeling and Prediction Division, \\ Denver, CO 80225, USA; gmccabe@usgs.gov \\ 5 U.S. Geological Survey Water Mission Area, Rapid City, SD 57702, USA; pnorton@usgs.gov \\ * Correspondence: wbattagl@usgs.gov
}

Received: 30 April 2020; Accepted: 9 June 2020; Published: 15 June 2020

check for updates

\begin{abstract}
The National Park Service (NPS) manages hundreds of parks in the United States, and many contain important aquatic ecosystems and/or threatened and endangered aquatic species vulnerable to hydro-climatic change. More effective management of park resources under future hydro-climatic uncertainty requires information on both baseline conditions and the range of projected future conditions. A monthly water balance model was used to assess baseline (1981-1999) conditions and a range of projected future hydro-climatic conditions in 374 NPS parks. General circulation model outputs representing 214 future climate simulations were used to drive the model. Projected future changes in air temperature $(\mathrm{T})$, precipitation $(p)$, and runoff $(\mathrm{R})$ are expressed as departures from historical baselines. Climate simulations indicate increasing T by 2030 for all parks with 50th percentile simulations projecting increases of $1.67^{\circ} \mathrm{C}$ or more in $50 \%$ of parks. Departures in $2030 p$ indicate a mix of mostly increases and some decreases, with 50th percentile simulations projecting increases in $p$ in more than $70 \%$ of parks. Departures in R for 2030 are mostly decreases, with the 50th percentile simulations projecting decreases in $\mathrm{R}$ in more than $50 \%$ of parks in all seasons except winter. Hence, in many NPS parks, $\mathrm{R}$ is projected to decrease even when $p$ is projected to increase because of increasing $\mathrm{T}$ in all parks. Projected changes in future hydro-climatic conditions can also be assessed for individual parks, and Rocky Mountain National Park and Congaree National Park are used as examples.
\end{abstract}

Keywords: national parks; continental models; hydro-climatic change; water resources management

\section{Introduction}

The National Park Service (NPS) mission is to preserve resources unimpaired for future generations [1]. Many NPS parks contain important aquatic ecosystems that may have threatened and/or endangered aquatic species vulnerable to hydro-climatic change. In addition to air temperature $(\mathrm{T})$ and precipitation $(p)$, runoff ( $\mathrm{R}$; streamflow per unit area in a drainage basin) is critical for sustaining these aquatic ecosystems. Projected future $\mathrm{T}$ and $p$ may result in changes to hydrologic conditions including $\mathrm{R}$ that may alter park aquatic conditions and associated ecosystems [2]. Additionally, many parks rely on surface and subsurface water for park facilities and to provide water to visitors. Changes to water supplies resulting from hydro-climatic change could fundamentally challenge key park operations, as well as increase potential water-rights conflicts in water scarce regions. Identifying 
potential future changes in R would improve the effectiveness of planning efforts within the NPS, especially for large capital expenditures made now that are expected to have a long design life [3].

Decision makers in natural resource management agencies (such as the NPS) desire plausible and relevant future climate projections $[4,5]$. Projections of future climate are commonly derived from general circulation models (GCMs), which simulate the physical processes that determine global climate [6]. The Coupled Model Intercomparison Projects (CMIP) GCM ensembles can be used by decision makers to examine a range of simulations from which future conditions can be explored and analyzed. These were developed through the World Climate Research Programme, working with guidelines from the Intergovernmental Panel on Climate Change (IPCC), to present numerous climate model projections for future conditions [6]. The climate model simulations are grouped into scenarios that represent different assumptions about future greenhouse gas emissions based on projected changes in demographics and on economic and technological development.

Because future projections of climate are highly uncertain, examining adaptation strategies over a broad array of plausible future scenarios could help resource managers make better informed decisions $[7,8]$. Assessments of aquatic conditions and associated ecosystem and species vulnerability, and effective management of NPS resources under future hydro-climatic change require detailed information of current conditions (baseline conditions) and the range of projected future conditions [9]. Because the dominant processes affecting hydrologic change vary spatially [10], there is a need to develop park specific (and, for some parks, inter-park specific) estimates of historical hydro-climatic conditions and projected future hydro-climatic changes to help park managers: (1) understand how flow regimes and hydrologic conditions may change in NPS parks into the future; (2) assess species and ecosystem vulnerability to future hydro-climatic changes in NPS parks; (3) develop proactive adaptation strategies to buffer the effects of climate-induced changes in runoff and other hydrologic conditions; and (4) anticipate future climatic and management demands on the water necessary to maintain park ecosystems (and the larger landscape they are embedded in) and water supplies vital for park use and visitation.

Prior studies have shown that T is likely to increase in NPS parks [4,11]. Projections of $p$ in NPS parks are inconsistent, showing increases and decreases depending on the climate model simulation. These previous studies do not provide information on future $\mathrm{R}$ for the parks, which can be provided by a monthly water balance model (MWBM). The potential range of future hydrologic change for many parks managed by the NPS is poorly understood [12].

To study the potential effects of future climatic conditions at the scale of individual NPS parks, which in the conterminous United States (CONUS) range from less than $0.1 \mathrm{~km}^{2}$ to more than $13,000 \mathrm{~km}^{2}$, climatological information is required on scales that are generally much finer than the typical grid size of even the highest-resolution GCMs [13]. To develop park specific estimates of projected future hydro-climatic changes, finer-resolution (downscaled) climate projections are required. Results from Hay et al. [14] indicate that many of the hydrologic model outputs simulated using downscaled GCM climate data may not be reliable for studies requiring analyses on daily or even weekly time scales. They concluded that until improved GCM simulations of daily precipitation are made available, estimates of future R may be most appropriately evaluated on a weekly, or longer, time step.

Monthly time steps of future R are available for the CONUS from an MWBM $[15,16]$. The MWBM was driven with downscaled $\mathrm{T}$ and $p$ from $95 \mathrm{GCMs}$, representing 214 climate model simulations, from phases 3 and 5 of the CMIPs (CMIP3 and CMIP5, respectively). Departures from baseline (1981-1999) conditions for 2030, 2060, and 2090 using the 214 climate simulations from Bock et al. [15] were summarized in the U.S. Geological Survey (USGS) data release by Hay [17] providing decision makers with a range of plausible futures to develop adaptation strategies. These departures were used by Maloney et al. [18] to model possible effects of land-use and climate changes on the condition of 70,772 small streams in the Chesapeake Bay watershed. In their study, the hydrologic response unit (HRU) departure values were rasterized at 30-m resolution and then added to historical climate 
estimates (1981-1999) to produce future projections of average seasonal temperature and total seasonal precipitation across the Chesapeake Bay watershed.

This paper shows an alternative method for applying the Hay [17] climate information using the NPS parks as an example. The objective of this study is to use MWBM output to assess baseline hydro-climatic conditions and the range in projected changes in future hydro-climatic conditions for NPS parks in the CONUS. Each national park has unique resources, concerns, and associated thresholds of concern. This paper focuses on $\mathrm{T}, p$, and $\mathrm{R}$, all of which are critical components needed by park managers to assess their unique aquatic and ecosystem vulnerability to hydro-climatic conditions in the recent past and projected changes in hydro-climatic conditions in response to future climatic conditions.

\section{Materials and Methods}

The analyses presented in this paper represent a unique approach for working with the MWBM [15,17] and the National Hydrologic Model (NHM) [19-21]. The MWBM output was used as the building block to examine hydro-climatic conditions for NPS parks across the CONUS. All MWBM inputs and outputs are available through the USGS MWBM futures portal [22] and can be accessed at https://my.usgs.gov/mows/.

\subsection{Monthly Water Balance Model (MWBM)}

The MWBM is a modular accounting system that provides monthly estimates of components of the hydrologic cycle [15,23-25]. The MWBM includes the concepts of climatic water supply and demand, seasonality in climatic water supply and demand, snow accumulation and melt, and soil-moisture storage. Climate drivers to the MWBM are monthly T, $p$, and potential evapotranspiration (PET); the latter is calculated from monthly $\mathrm{T}$ using the Hamon equation [26]. For additional details of the MWBM, see the work of McCabe and Markstrom [24].

The MWBM was calibrated and used to produce historical and future hydro-climatic outputs for the CONUS. Methods used to calibrate and parameterize the CONUS-scale MWBM were detailed by Bock et al. [15,27]. The CONUS-scale calibrated MWBM was driven with T, $p$, and PET for the period 1950-2099 using the 109,951 HRUs from the Geospatial Fabric for National Hydrologic Modeling [28]. The Geospatial Fabric is a set of hydrographic features aggregated from the National Hydrography Dataset Plus version one [29] at a scale appropriate for regional and national hydrologic modeling and analysis across the CONUS. HRU areas range from less than $1 \mathrm{~km}^{2}$ to $67,991 \mathrm{~km}^{2}$, depending on drainage density, with an average size of $74 \mathrm{~km}^{2}$.

\subsection{Baseline Conditions}

The MWBM application of the NHM was calibrated for the CONUS by Bock et al. [27] using $\mathrm{T}$ and $p$ downloaded through the USGS Geo Data Portal (GDP; https://cida.usgs.gov/gdp/) [30]. The 1/8th-degree gridded (about $140 \mathrm{~km}^{2}$ ) spatial resolution T and $p$ dataset for 1949-2010 was produced by Maurer et al. [31] and represents historical measured climatic conditions. The daily time step gridded values of $\mathrm{T}$ and $p$ were transferred to the 109,951 HRUs from the geospatial fabric across the CONUS [27] by the GDP using an area-weighted averaging algorithm, and then aggregated up to a monthly time step. Baseline climatic conditions reported in this study are based on this MWBM output from 1981 to 1999 and are shown on Figure 1. 


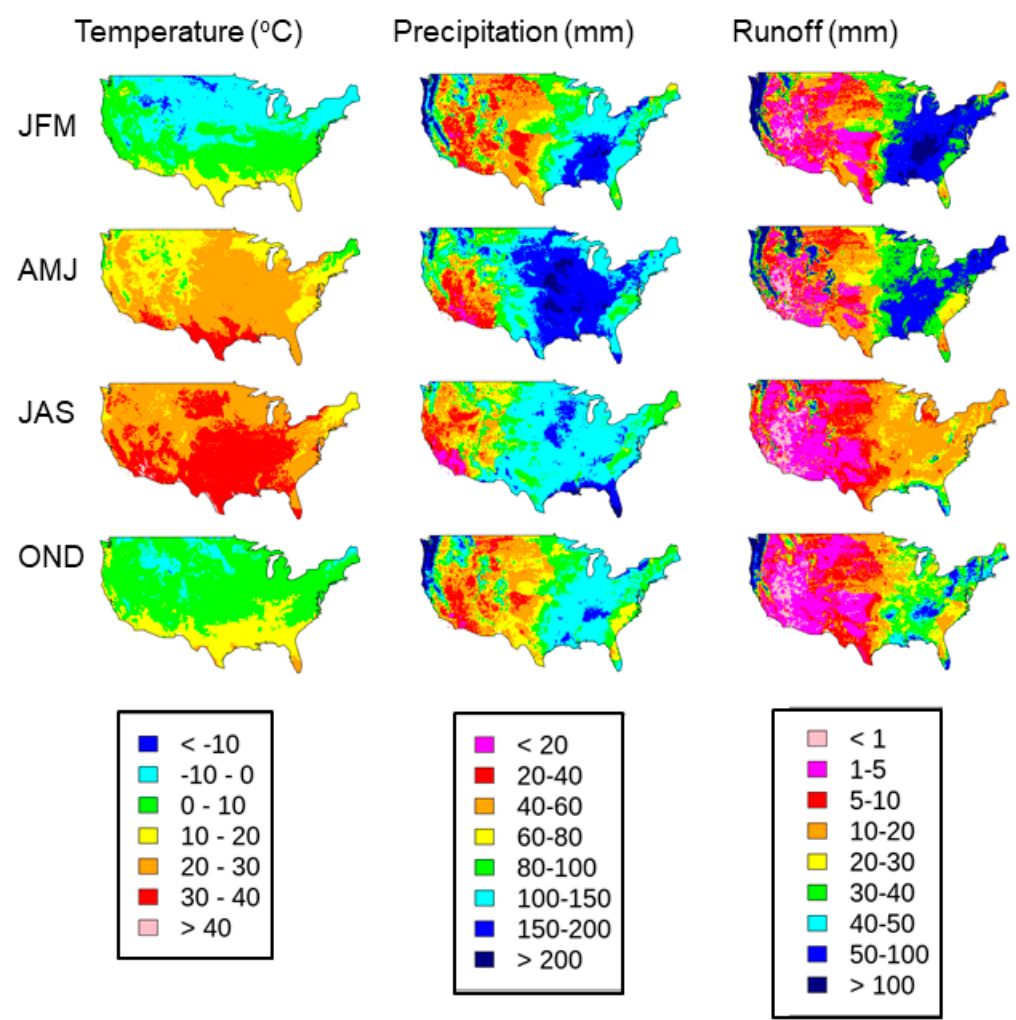

Figure 1. Baseline (1981-1999) climatic conditions for seasonal average monthly temperature in degrees Celsius $\left({ }^{\circ} \mathrm{C}\right)$, precipitation in millimeters $(\mathrm{mm})$, and runoff in $\mathrm{mm}$. JFM, January-March; AMJ, April-June; JAS, July-September; OND, October-December.

\subsection{Future Conditions}

The MWBM application of the NHM was driven with statistically downscaled T and $p$ from 95 GCMs (38 CMIP3 GCMs and 57 CMIP5 GCMs), representing 214 climate simulations [22] from 1950 to 2099. Statistical downscaling is a technique for deriving fine-scale interpolations from coarse-scale GCMs based on statistical relations between observed local-scale climate data, such as meteorological observations or gridded station data derived from historical climate observations, and the coarse-scale GCM variables [32]. The GCM simulations used in this analysis were statistically downscaled using the bias-correction and spatial disaggregation (BCSD) methodology [32-35]. The 214 climate simulations were summarized using the GDP for the 109,951 HRUs from the geospatial fabric across the CONUS [28].

The 214 GCM climate simulations from CMIP3 and CMIP5 are composed of the Special Report on Emission Scenarios (SRES) B1, A1B, and A2 for CMIP3, and the Representative Concentration Pathways (RCPs) 4.5, 6, and 8.5 for CMIP5 [34,35]. These scenarios/pathways represent assumptions about future greenhouse gas emissions, accounting for short- and long-term climate cycles, and anthropogenic drivers such as changes in demographics and economic and technological development $[36,37]$. Climatic conditions represented by these scenarios range from stabilized populations after 2050, coupled with rapid development of more efficient technological systems across the globe (A1B, RCP4.5), to globally increasing populations and regionally oriented economic development (A2, RCP8.5). For a full description of the differences between the climate scenarios, consult IPCC [36] for CMIP3, and Taylor et al. [37] for CMIP5. Appendices 1 and 2 from Bock et al. [22] list the 214 GCM climate simulations.

For each of the 214 climate simulations and each of the 109,951 HRUs, Hay [17] summarized projections of future T, $p$, and R from the MWBM as seasonal changes (departures) from each climate simulation's historical GCM baseline (1981-1999). The GCM baselines are unique for each GCM simulation and are not the same as the MWBM baseline values as described above in Section 2.2. Thus, 
all projected values of T, $p$, and R from the MWBM were expressed as a departure from the T, $p$, and R GCM baselines for each respective climate simulation for each of the 109,951 HRUs. The seasons were defined as winter (January-March (JFM)), spring (April-June (AMJ)), summer (July-September (JAS)), and fall (October-December (OND)). Departures of T, p, and R from the historical GCM baseline were expressed as average monthly seasonal departures for three future periods, 19 years in length, centered on 2030 (2021-2039), 2060 (2051-2069), and 2090 (2081-2099).

For each MWBM variable (T, $p$, and R), each season (JFM, AMJ, JAS, and OND), and each period (2030, 2060, and 2090), the 5th, 25th, 50th, 75th, and 95th percentiles of T, $p$, and R departures for the 214 climate simulations were computed for each of the 109,951 HRUs [17].

\subsection{NPS Study Areas}

The NPS manages 419 parks (as of 2019) [1]. Of these, 374 parks (89\%) were selected for this study (Figure 2 and Table S1). NPS parks were excluded if they were located outside of the CONUS, located offshore, included a substantial coastal component, or straddled an international border because the Geospatial Fabric incompletely covered these areas. Unfortunately, this excludes some important parks such as Everglades National Park and Isle Royale National Park for which more specialized analysis would be required.

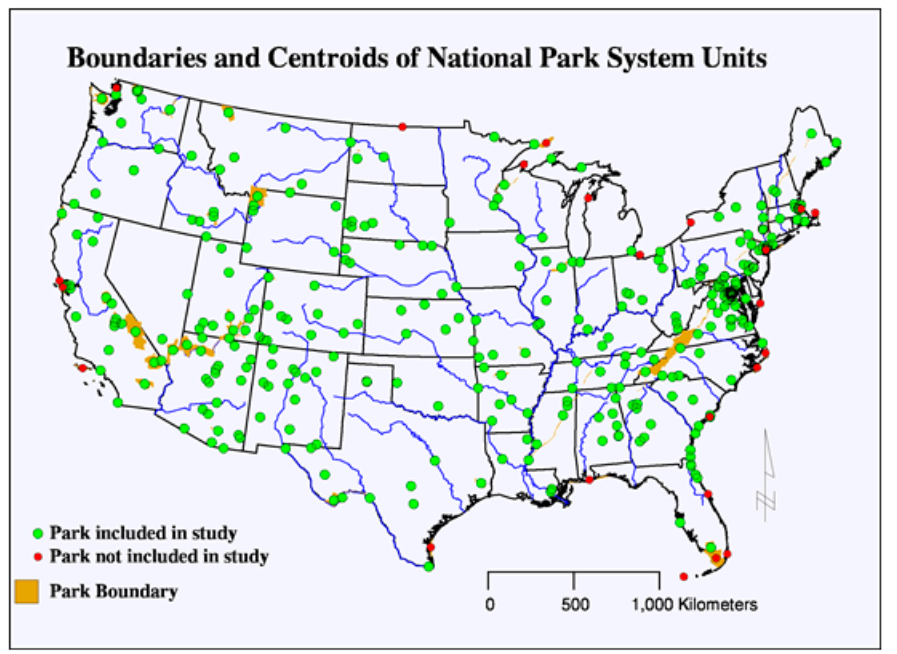

Figure 2. Map showing boundaries and centroids of national parks in the conterminous United States that were (and were not) included in this study.

Outputs from the MWBM application of the NHM (baseline conditions based on the Maurer data [31] and future conditions) were summarized for selected NPS parks located within the CONUS. Area-weighted transfer functions were used to calculate park summaries of baseline and projected future hydro-climatic conditions ( $\mathrm{T}, p$, and $\mathrm{R}$ ) for all HRUs that are wholly, or in part, within park boundaries for the 374 NPS parks in this study. Some parks fall completely within a single HRU and were represented by that single HRU in this study.

\section{Results}

The following sections examine the seasonal changes in average monthly $T, p$, and $\mathrm{R}$ for the CONUS and also assess baseline and seasonal changes for selected NPS parks. The changes in $\mathrm{T}$ are presented in degrees Celsius $\left({ }^{\circ} \mathrm{C}\right)$. The changes in $p$ and $\mathrm{R}$ are presented in millimeters (mm). Section 3.1 reviews the hydro-climatic changes for the CONUS based on the results presented in the Hay [17] data release. These results are presented for 2030, 2060, and 2090 from 214 climate simulations as departures (by model output percentile) and ranges of departures. Section 3.2 describes how these hydro-climatic changes can be assessed locally using the NPS parks as an example. 


\subsection{Hydro-Climatic Change in the CONUS}

Figures 3-5 show the departures of T, p, and R from the historical GCM baselines [17]. These departures as shown by model output percentile for 2030, 2060, and 2090 and are mapped to illustrate the spatial distributions of changes from the 214 climate simulations. T increases for all percentiles and for all periods (2030-2090, Figure 3). For most seasons and periods, there also seems generally to be greater warming in the interior CONUS compared with coastal regions. By 2030, the 50th percentile T departures are between 1 and $3{ }^{\circ} \mathrm{C}$, with the 5 th percentile departures between 0 and $2{ }^{\circ} \mathrm{C}$, and the 95 th percentile departures between 3 and $5^{\circ} \mathrm{C}$. By 2060, the 50th percentile $\mathrm{T}$ departures are larger than $3{ }^{\circ} \mathrm{C}$, with the 5 th percentile departures between 0 and $3{ }^{\circ} \mathrm{C}$, and the 95 th percentile departures larger than $5^{\circ} \mathrm{C}$ for most of the CONUS for all seasons. By 2090, the 50th percentile $\mathrm{T}$ departures are generally $4{ }^{\circ} \mathrm{C}$ or larger, with the 5 th percentile departures generally between 1 and $3{ }^{\circ} \mathrm{C}$, and the 95 th percentile departures larger than $6^{\circ} \mathrm{C}$ for much of the CONUS for all seasons.

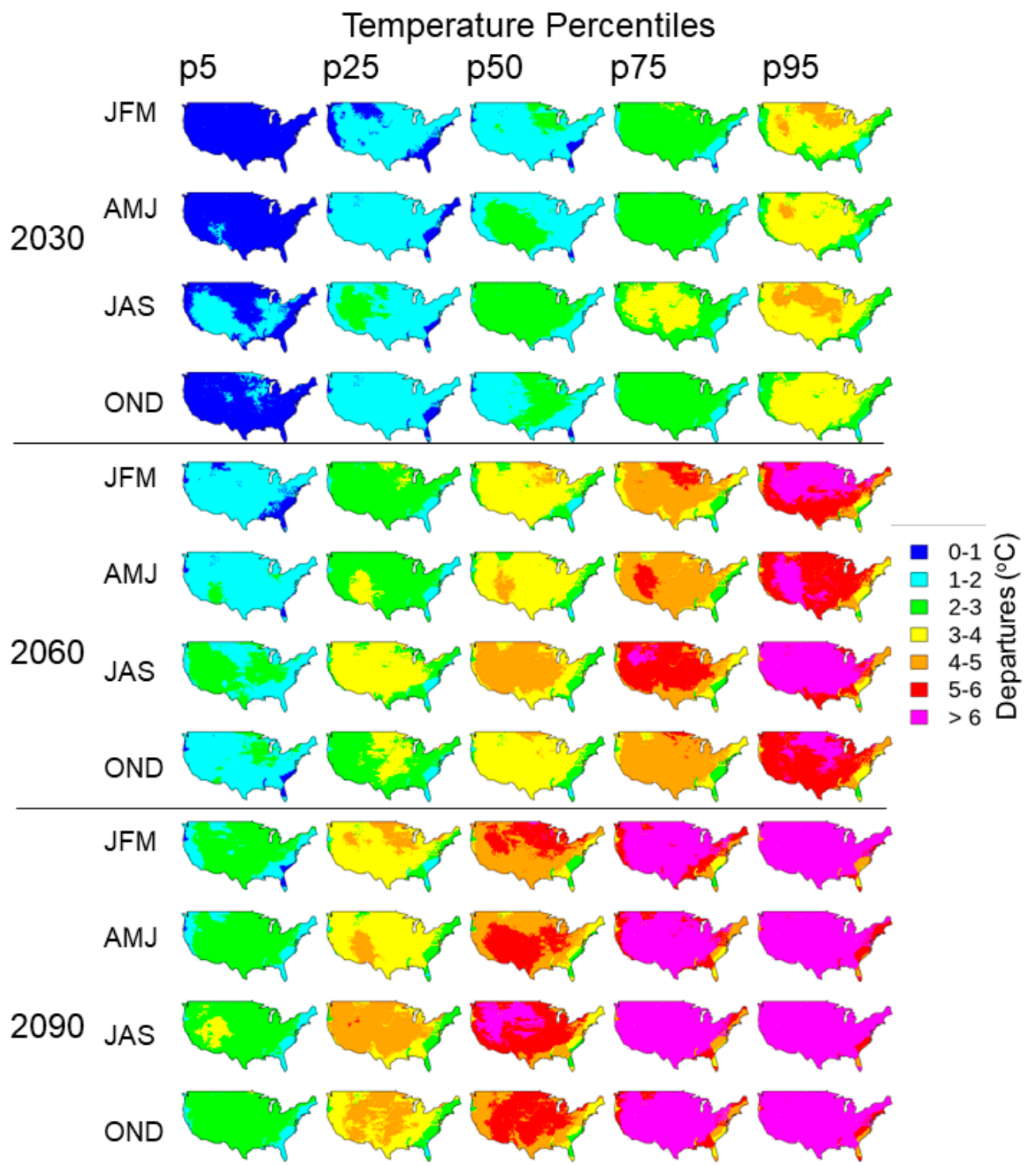

Figure 3. Departures in seasonal average monthly temperature in degrees Celsius $\left({ }^{\circ} \mathrm{C}\right)$ by percentiles (5th, 25th, 50th, 75th, and 95th) projected for 2030, 2060, and 2090 from 214 climate simulations. JFM, January-March; AMJ, April-June; JAS, July-September; OND, October-December. 


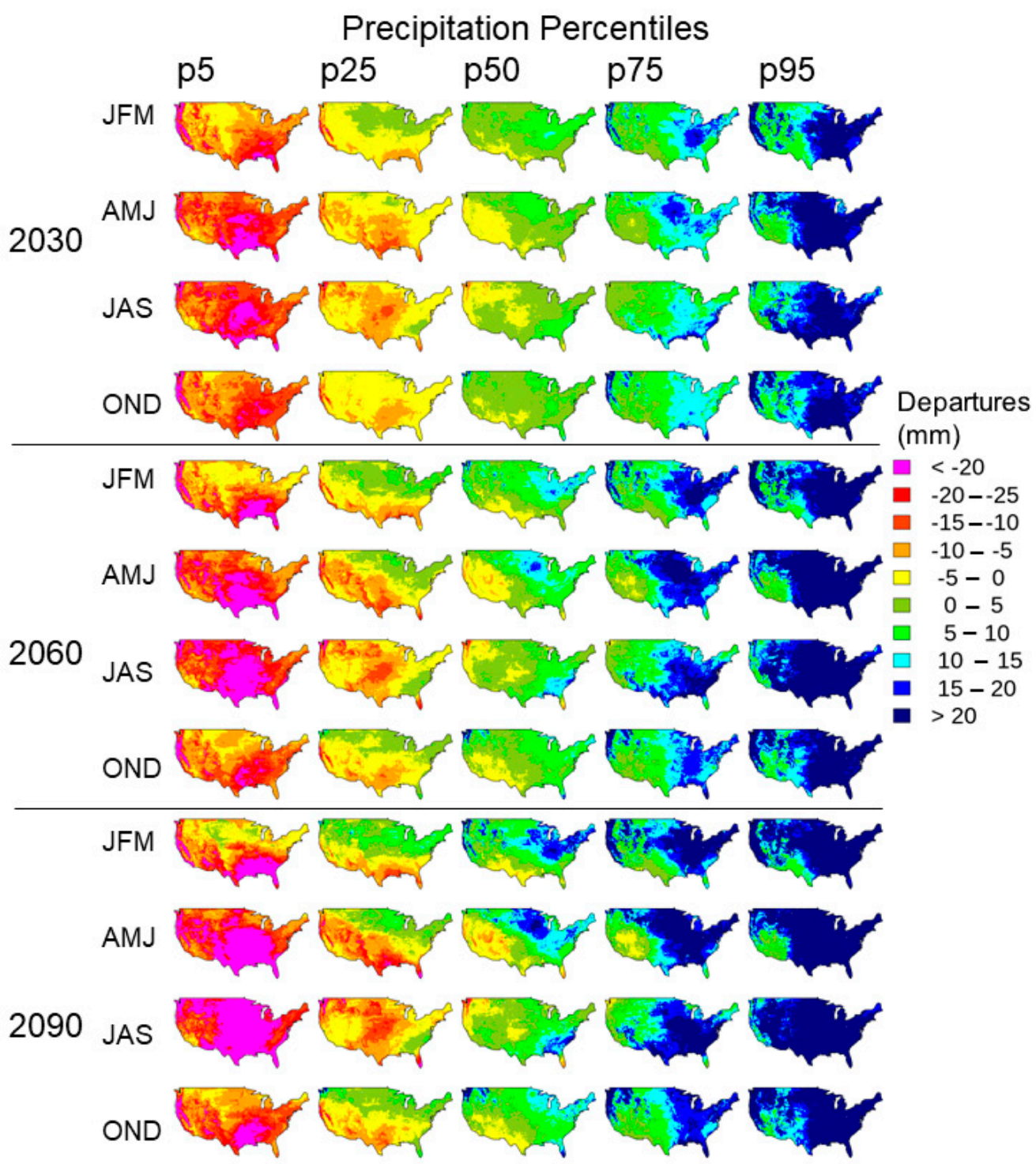

Figure 4. Departures in seasonal average monthly precipitation in millimeters $(\mathrm{mm})$ by percentiles (5th, 25th, 50th, 75th, and 95th) projected for 2030, 2060, and 2090 from 214 climate simulations. JFM, January-March; AMJ, April-June; JAS, July-September; OND, October-December.

In contrast to the consistently positive $\mathrm{T}$ departures (Figure 3), the patterns in $p$ departures indicate large uncertainty in future $p$, showing a wide range in future projections. The 5 th percentile shows decreases in $p$ for most of the CONUS that shift to increases in $p$ for the 95th percentile projections (Figure 4). In 2030, 2060, and 2090, the 50th percentile $p$ departures are positive in all four seasons for most of the CONUS (Figure 4), which means that more than half of the climate simulations project increases in $p$ in all seasons over most of the CONUS.

In general, projected departures in R (Figure 5) are smaller in magnitude than the projected departures in $p$ (Figure 4). Similar to the patterns of departures in $p$, the $\mathrm{R}$ departure patterns indicate large uncertainty in future $\mathrm{R}$. The 5 th percentile shows decreases in $\mathrm{R}$ for most of the CONUS, whereas the 95th percentile projections of $R$ are increases (Figure 5). In 2030, 2060, and 2090, the 50th percentile $R$ departures are negative in three of four seasons for most of the CONUS, with the exception of the JFM (winter) season, which means that more than half of the climate simulations project decreases in $\mathrm{R}$ over most of the CONUS except in winter, which is in contrast to the projected increases in $p$ for most of the CONUS. 


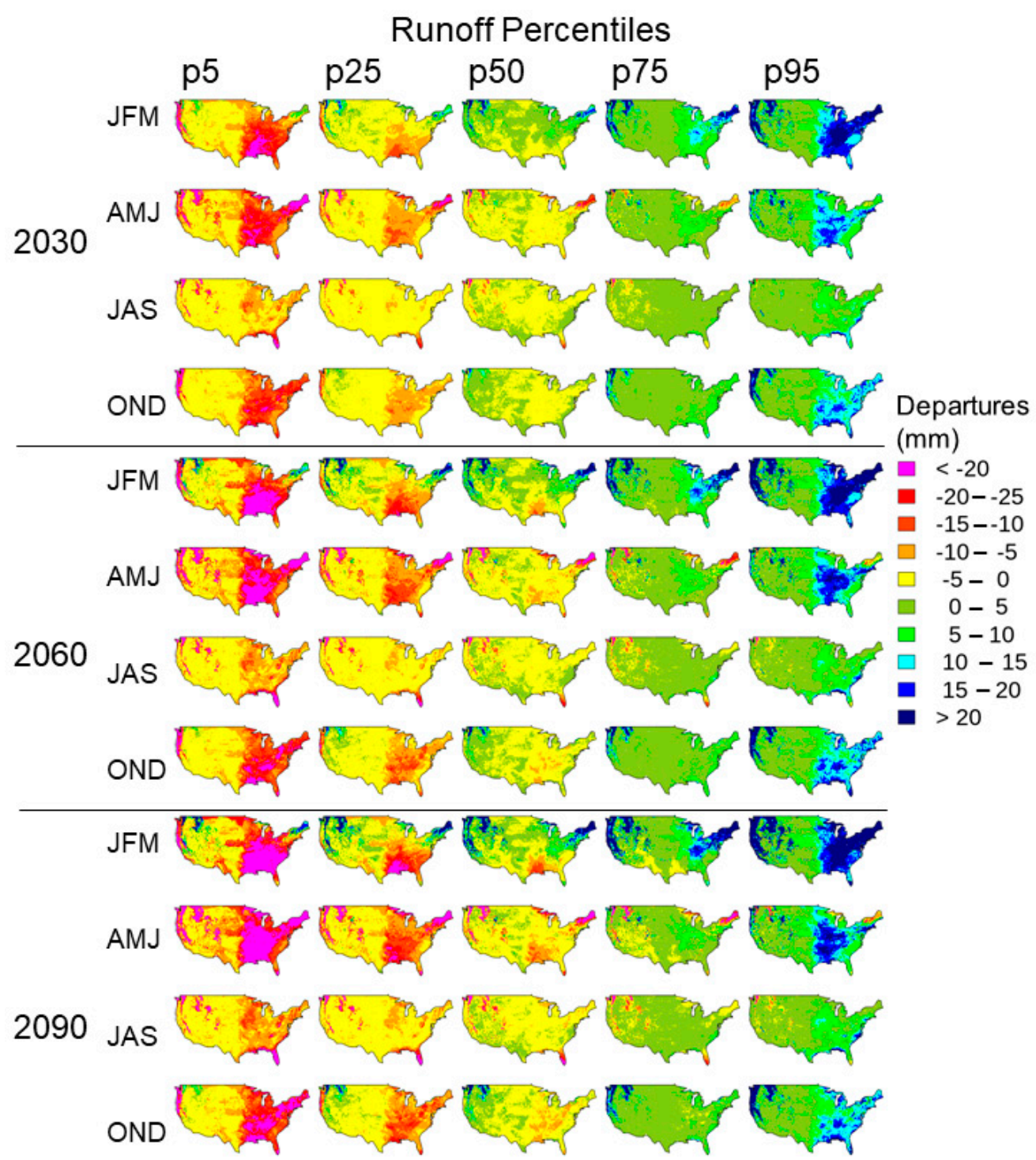

Figure 5. Departures in seasonal average monthly runoff in millimeters $(\mathrm{mm})$ by percentiles (5th, 25th, 50th, 75th, and 95th) projected for 2030, 2060, and 2090 from 214 climate simulations. JFM, January-March; AMJ, April-June; JAS, July-September; OND, October-December.

The range in MWBM outputs produced using the 214 GCM climate simulations provides an indication of the uncertainty or variation in plausible future climatic projections. Figure 6 shows the range (95th percentile - 5th percentile) of departures in T, $p$, and R projected for 2030, 2060, and 2090 from 214 climate simulations mapped for the CONUS.

By 2030, the range of projected departures in $\mathrm{T}$ is generally less than $4{ }^{\circ} \mathrm{C}$. The largest ranges in $\mathrm{T}$ departures are for the JFM season in the north central CONUS and the smallest ranges in T departures are for the eastern and western portions of the CONUS. The range in $\mathrm{T}$ departures increases from 2030 to 2060 and 2090, with the smallest ranges remaining in the eastern and western portions of the CONUS. The increasing range in T departures between 2030 and 2090 indicates increasing uncertainty in projected $\mathrm{T}$ into the future (Figure 6).

Compared to $\mathrm{T}$, the ranges of projected departures in $p$ are highly variable across the CONUS (Figure 6). A consistent pattern for 2030, 2060, and 2090 is observed, with the largest range in $p$ departures for western portions of the CONUS for JFM and OND, and the mid-Atlantic portion of the CONUS for all seasons to a varying spatial degree. The increasing range in $p$ departures between 2030 and 2090 indicates increasing uncertainty in projected $p$ into the future (Figure 6). 


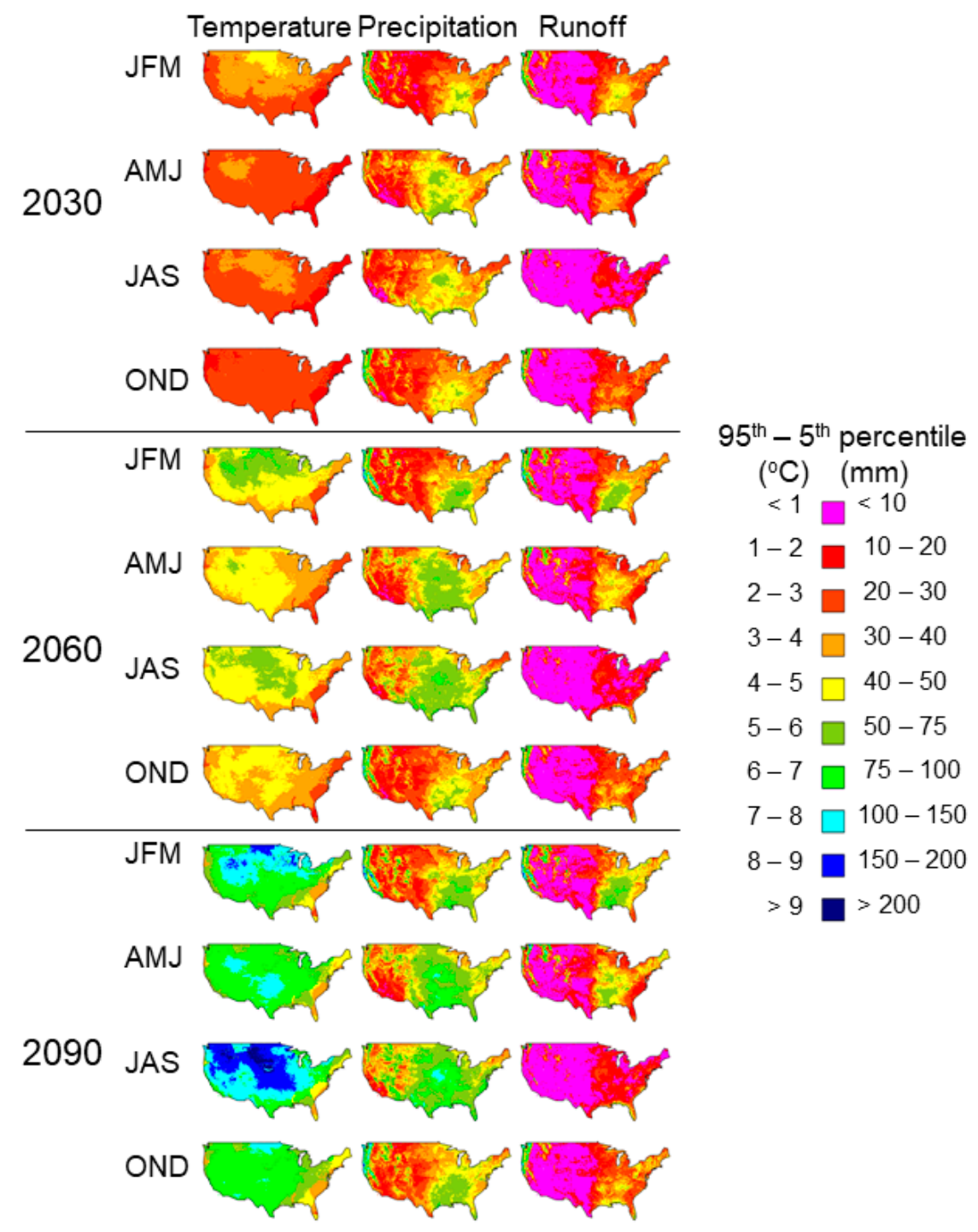

Figure 6. Range (95th percentile - 5th percentile) of departures in seasonal average monthly temperature in degrees Celsius $\left({ }^{\circ} \mathrm{C}\right)$, and precipitation and runoff in millimeters (mm) projected for 2030, 2060, and 2090 from 214 climate simulations. JFM, January-March; AMJ, April-June; JAS, July-September; OND, October-December.

The ranges of projected departures in R also are variable across the CONUS with generally smaller values than for $p$ (Figure 6). The largest range in R departures is in JFM in the Pacific northwestern and mid-Atlantic portions of the CONUS. Areas of the CONUS with the largest range in R departures do not necessarily correspond (either spatially or seasonally) to the areas with largest range in $p$ departures. The increasing range in $\mathrm{R}$ departures between 2030 and 2090 is not as apparent as for $\mathrm{T}$ and $p$ (Figure 6) perhaps due to the large range in baseline R magnitudes (Figure 1).

Ratio of the Range of Projected Changes (2030, 2060, and 2090) to Baseline

The absolute magnitude of departures in projected future $p$ and $\mathrm{R}$, and the magnitude of the range in these projected departures may not provide the best indication of potential aquatic and ecosystem vulnerability. This is due, in part, to the confounding influence of the strong correlations between baseline $p$ and $\mathrm{R}$ and the respective magnitudes of projected ranges in projected $p$ and $\mathrm{R}$ departures. An alternative indicator may be the ratio of the ranges in projected departures from baseline climatic conditions to those baseline conditions (calculated as [95th percentile - 5th percentile]/baseline). Larger ratios (more than 1) indicate that the range in projected departures for an area is larger than 
the baseline condition, demonstrating greater potential importance of those changes than for an area where this value is smaller (less than 1). For example, if the range in model projections for $\mathrm{R}$ were $20 \mathrm{~mm}$ and the baseline $\mathrm{R}$ were $20 \mathrm{~mm}$, then that variation in model outputs could be important to consider; however, if the range were the same and the baseline $\mathrm{R}$ were $200 \mathrm{~mm}$, then that variation in model outputs would be less important to consider.

The ratio of the ranges in project departures in $p$ and $\mathrm{R}$ to baseline conditions across the CONUS for 2030, 2060, and 2090 are shown on Figure 7. By 2030, for most of the CONUS, the ratio for $p$ is less than 0.5 which indicates that the uncertainty in projected changes in $p$ are less than half the magnitude of baseline $p$. The ratio is greater than 1 for $p$ only during the summer (JAS) months in 2060 and 2090 in parts of the arid western U.S. In contrast, the ratio is greater than 1 for $\mathrm{R}$ in some locations across the CONUS in all seasons starting in 2030 (Figure 7). Hence, while in many areas the magnitudes of $\mathrm{R}$ departures are relatively small (Figure 6), the range (or uncertainty in model projections) is larger than the baseline conditions (Figure 7), indicating that it could have great potential importance to local hydro-climatic conditions.

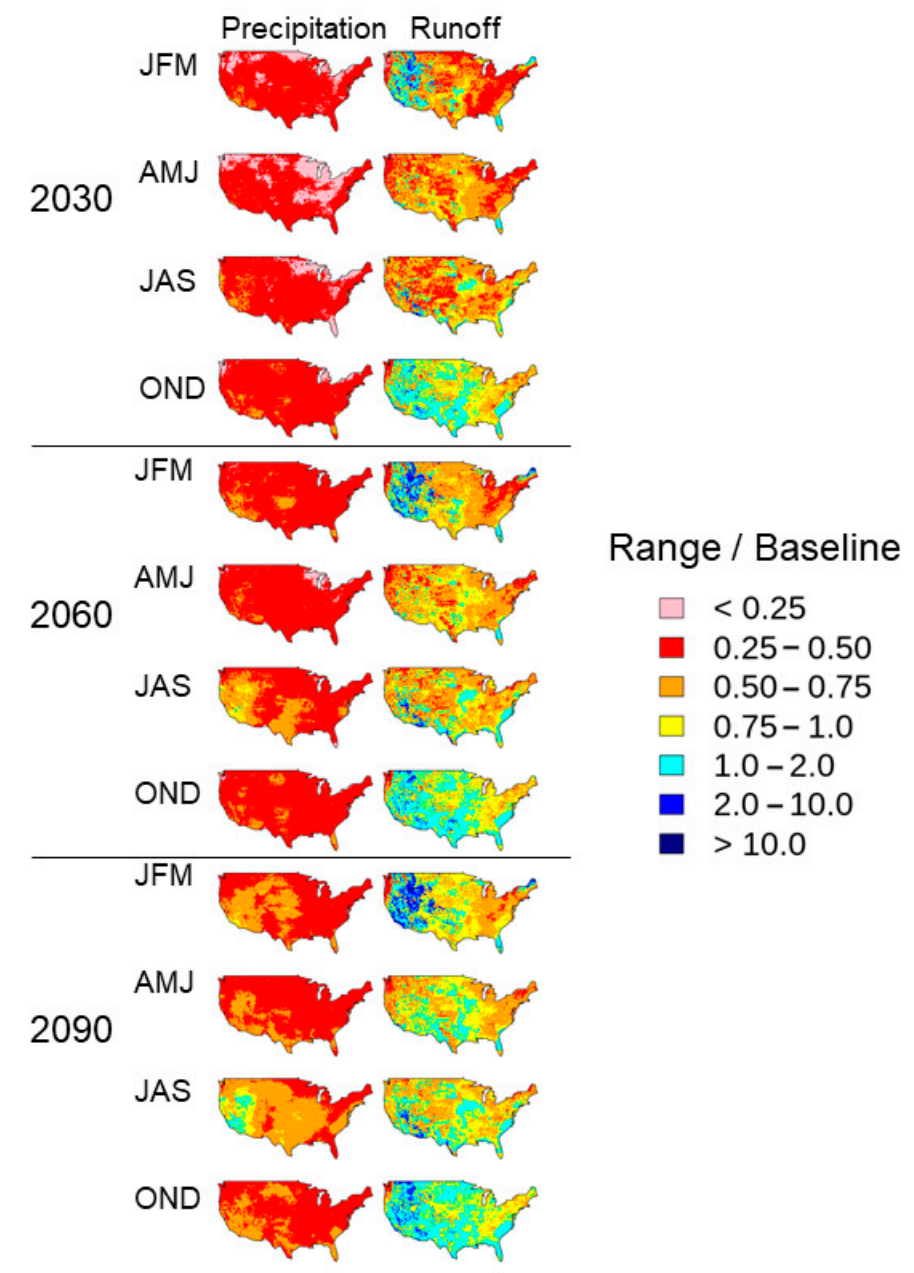

Figure 7. Range (95th percentile - 5th percentile) of departures divided by the baselines in seasonal average monthly precipitation and runoff projected for 2030, 2060, and 2090 from 214 climate simulations. JFM, January-March; AMJ, April-June; JAS, July-September; OND, October-December.

\subsection{Hydro-Climatic Change in the National Parks}

Ranges in hydro-climatic changes experienced by parks in different parts of the CONUS have very different consequences depending on the initial (or baseline) climatic conditions. The following 
sections put these projected changes in perspective of the NPS parks by comparing them with local NPS park baseline conditions.

\subsubsection{Baseline Climatic Conditions (1981-1999)}

Average baseline (1981-1999) climatic conditions for T, $p$, and R for each season for each of the 374 NPS parks were calculated by area weighting the appropriate HRU values. The results are summarized in Table 1 and provided for each NPS park in Tables S2-S5. Baseline T ranged from a minimum of $-11.5^{\circ} \mathrm{C}$ (coldest park in coldest season) to a maximum of $40.5{ }^{\circ} \mathrm{C}$ (warmest park in warmest season). Baseline $p$ ranged from a minimum of $15.3 \mathrm{~mm}$ (driest park in driest season) to a maximum of $414 \mathrm{~mm}$ (wettest park in wettest season). Baseline $\mathrm{R}$ ranged from a minimum of $0.30 \mathrm{~mm}$ (least runoff in any park and season) to a maximum of $313 \mathrm{~mm}$ (most runoff in any park and season) (Table 1).

Table 1. Summary statistics for baseline (1981-1999) climatic conditions for average monthly temperature (T), precipitation $(p)$, and runoff $(\mathrm{R})$ for each season, for the 374 National Park Service parks.

\begin{tabular}{ccccc}
\hline Baseline Climatic Condition & January-March & April-June & July-September & October-December \\
\hline $\mathrm{T},{ }^{\circ} \mathrm{C}$-minimum & -11.5 & 6.82 & 14.1 & -7.72 \\
$\mathrm{~T},{ }^{\circ} \mathrm{C}$-median & 1.10 & 21.8 & 28.9 & 6.85 \\
$\mathrm{~T},{ }^{\circ} \mathrm{C}$-maximum & 20.2 & 36.1 & 40.5 & 23.8 \\
$p, \mathrm{~mm}$-minimum & 25.5 & 21.4 & 15.3 & 24.8 \\
p, mm-median & 106 & 133 & 118 & 102 \\
$p, \mathrm{~mm}$-maximum & 381 & 225 & 219 & 414 \\
$\mathrm{R}, \mathrm{mm}$-minimum & 1.28 & 0.78 & 0.30 & 0.75 \\
$\mathrm{R}, \mathrm{mm}$-median & 55.3 & 46.6 & 15.6 & 26.7 \\
$\mathrm{R}, \mathrm{mm}$-maximum & 253 & 238 & 196 & 313 \\
\hline
\end{tabular}

\subsubsection{Percentiles of Change (2030)}

As indicated by the CONUS results, uncertainty in the projections of $\mathrm{T}, p$, and $\mathrm{R}$ increases from 2030 to 2090. The 2030 (i.e., 2021-2039) period is of immediate concern to the NPS, given planning processes generally focus on the next 5-20 years [38]. Therefore, the following sections present projected departures in T, $p$, and $\mathrm{R}$ for parks specifically for the 2030 period. Departures in seasonal average monthly T, $p$, and R by percentiles (5th, 25th, 50th, 75th, and 95th) projected for 2030 from 214 climate simulations for each of the 374 NPS parks were calculated by area weighting the appropriate HRU values. These departures from GCM baseline conditions are summarized by season in Table 2 and provided for each NPS park in Tables S2-S5.

Table 2. Summary statistics for 214 climate simulations of projected 2030 departures in average monthly temperature $(T)$, precipitation $(p)$, and runoff $(\mathrm{R})$ by 5th, 50th, and 95th percentile models for each season, for the 374 National Park Service parks.

\begin{tabular}{ccccc}
\hline $\begin{array}{c}\text { Median Projected 2030 } \\
\text { Departures for }\end{array}$ & January-March & April-June & July-September & October-December \\
\hline $\mathrm{T},{ }^{\circ} \mathrm{C}$-5th percentile simulations & 0.38 & 0.74 & 0.90 & 0.78 \\
$\mathrm{~T},{ }^{\circ} \mathrm{C}$-50th percentile simulations & 1.67 & 1.79 & 2.16 & 1.85 \\
$\mathrm{~T},{ }^{\circ} \mathrm{C}$-95th percentile simulations & 3.12 & 3.02 & 3.42 & 3.05 \\
p, mm-5th percentile simulations & -10.3 & -12.3 & -13.2 & -12.4 \\
$p, \mathrm{~mm}$-50th percentile simulations & 5.18 & 3.06 & 2.92 & 3.84 \\
$p, \mathrm{~mm}$-95th percentile simulations & 22.8 & -12.0 & -4.47 & -10.3 \\
$\mathrm{R}, \mathrm{mm}$-5th percentile simulations & -7.82 & -0.75 & -0.10 & -0.06 \\
$\mathrm{R}, \mathrm{mm}$-50th percentile simulations & 1.80 & 9.84 & 4.69 & 11.8 \\
$\mathrm{R}, \mathrm{mm}$-95th percentile simulations & 16.1 & &
\end{tabular}

The dominant patterns of projected 2030 changes in T for NPS parks were increases for all seasons for almost all percentiles (Tables S2-S5). Medians of the 50th percentile T departures in 2030 for the 374 parks were all increases ranging from $1.67^{\circ} \mathrm{C}$ in JFM to $2.16^{\circ} \mathrm{C}$ in JAS (Table 2). The 50th percentile climate simulations used in this study projected increases in temperature of $1.67^{\circ} \mathrm{C}$ or more in $52 \%$ of 
parks in JFM, $68 \%$ of parks in AMJ, $80 \%$ of parks in JAS, and 72\% of parks in OND (Tables S2-S5). More extreme projections of change from the 5th and 95th percentile models ranged from a minimum median T departure of $0.38^{\circ} \mathrm{C}$ to a maximum median T departure of $3.42{ }^{\circ} \mathrm{C}$ (Table 2).

The patterns of projected 2030 changes in $p$ for NPS parks for each season indicated a mix of increases and decreases (Tables S2-S5). Medians of the 50th percentile $p$ departures in 2030 for the 374 parks were all increases ranging from $2.92 \mathrm{~mm}$ in JAS to $5.18 \mathrm{~mm}$ in JFM (Table 2). The 50th percentile climate simulations projected increases in precipitation in 93\% of parks in JFM, 74\% of parks in AMJ, $80 \%$ of parks in JAS, and $94 \%$ of parks in OND (Tables S2-S5). More extreme projections of change from the 5th and 95th percentile models ranged from a minimum median $p$ departure of $-13.2 \mathrm{~mm}$ to a maximum median $p$ departure of $25.0 \mathrm{~mm}$ (Table 2).

The patterns of projected 2030 changes in R for NPS parks for each season indicate a mix of increases and decreases that were generally smaller in magnitude than projected changes in $p$ (Tables S2-S5). Medians of the 50th percentile departures in $\mathrm{R}$ in 2030 for the 374 parks ranged from $-0.75 \mathrm{~mm}$ in AMJ to $1.80 \mathrm{~mm}$ in JFM (Table 2). The 50th percentile climate simulations projected decreases in R in $22 \%$ of parks in JFM, $82 \%$ of parks in AMJ, 63\% of parks in JAS, and 52\% of parks in OND (Tables S2-S5). More extreme projections of change from the 5 th and 95th percentile models ranged from a minimum median $\mathrm{R}$ departure of $-12.3 \mathrm{~mm}$ to a maximum median $p$ departure of $16.1 \mathrm{~mm}$ (Table 2).

\subsubsection{Range of Projected Changes (2030)}

The projected ranges (95th percentile - 5th percentile) of seasonal departures in T, $p$, and R in 2030 for the 374 parks are summarized in Table 3 and provided for each NPS park in Tables S2-S5. The projected range of T, $p$, and $\mathrm{R}$ departures (Figure 6) and the ratio to baseline conditions (Figure 7) allow park managers to assess the potential changes a park may experience, with a wider range or larger ratio indicating greater uncertainty in future conditions and greater potential importance of departures to local hydro-climatic conditions. For example, these ranges and ratios could be used to construct divergent scenarios of plausible future hydro-climatic conditions a park may experience to evaluate vulnerability for a given set of resources with known climate sensitivities [39] and against which they can assess and test adaptation planning strategies.

Table 3. Summary statistics for 214 climate simulations of projected 2030 ranges (95th percentile -5 th percentile) of departures in average monthly temperature (T), precipitation $(p)$, and runoff $(\mathrm{R})$ for each season, for the 374 National Park Service parks.

\begin{tabular}{|c|c|c|c|c|}
\hline $\begin{array}{l}\text { Projected } 2030 \text { Range in } \\
\text { Departures for }\end{array}$ & January-March & April-June & July-September & October-December \\
\hline $\mathrm{T},{ }^{\circ} \mathrm{C}-$ minimum & 1.34 & 1.11 & 1.05 & 1.45 \\
\hline $\mathrm{T},{ }^{\circ} \mathrm{C}$-maximum & 4.44 & 3.65 & 3.58 & 2.72 \\
\hline$p, \mathrm{~mm}-$ minimum & 9.05 & 8.74 & 7.11 & 10.5 \\
\hline$p, \mathrm{~mm}$-median & 33.1 & 38.7 & 37.0 & 33.4 \\
\hline $\mathrm{R}, \mathrm{mm}-$ minimum & 0.53 & 0.63 & 0.33 & 0.52 \\
\hline $\mathrm{R}, \mathrm{mm}$-median & 27.1 & 23.5 & 9.90 & 22.7 \\
\hline $\mathrm{R}, \mathrm{mm}$-maximum & 121 & 75.4 & 106 & 96.2 \\
\hline
\end{tabular}

Medians of the 2030 ranges in seasonal T departures for the 374 parks were between $2.23{ }^{\circ} \mathrm{C}$ in AMJ and $2.64{ }^{\circ} \mathrm{C}$ in JFM (Table 3) and do not vary much by season. The minimum 2030 range in seasonal $\mathrm{T}$ departures was $1.05^{\circ} \mathrm{C}$ and the maximum range was $4.44^{\circ} \mathrm{C}$. The small variation in ranges (maximum minus minimum, Table 3 ) of seasonal $\mathrm{T}$ departures indicate relative certainty in projections of future $\mathrm{T}$.

Medians of the 2030 ranges in seasonal $p$ departures for the 374 parks were between $33.1 \mathrm{~mm}$ in JFM and $38.7 \mathrm{~mm}$ in AMJ (Table 3) and do not vary much by season. The minimum 2030 range 
in seasonal $p$ departures was $7.11 \mathrm{~mm}$ and the maximum range was $103 \mathrm{~mm}$. The large variation in ranges of seasonal $p$ departures indicates large uncertainty in projections of future $p$.

Medians of the 2030 ranges in seasonal R departures for the 374 parks were between $9.90 \mathrm{~mm}$ in JAS and $27.1 \mathrm{~mm}$ in JFM (Table 3) and they vary substantially by season. The minimum 2030 range in seasonal $\mathrm{R}$ departures was $0.33 \mathrm{~mm}$ and the maximum range was $121 \mathrm{~mm}$. Projections of $\mathrm{R}$ incorporate the uncertainty in projections of both $\mathrm{T}$ and $p$. The larger variation in ranges (maximum minus minimum, Table 3) of seasonal $R$ departures indicates greater uncertainty in projections of future $\mathrm{R}$ than for future $p$.

\subsubsection{Ratio of the Range of Projected Changes (2030) to Baseline Conditions}

The ratios of the projected ranges in future $p$ and $\mathrm{R}$ departures to their respective baselines by season for 2030 are summarized in Table 4 and provided for each NPS park in Tables S2-S5. The median seasonal ratios of the projected range in $p$ departures to baseline $p$ were between 0.28 and 0.34 and do not vary much by season (Table 4 ). The minimum seasonal ratio was 0.18 and the maximum seasonal ratio was 0.66 ; hence, no parks had $p$ ratios that exceeded 1 , and the range in ratio values was relatively small (Table 4). The median seasonal ratios of baseline $\mathrm{R}$ to the projected range in $\mathrm{R}$ departures were between 0.50 and 0.80 and vary some by season (Table 4). The minimum seasonal ratio was 0.22 , and the maximum seasonal ratio was 4.03 . Forty-five parks $(12 \%)$ had $\mathrm{R}$ ratios greater than 1 in JFM, 7 parks $(1.9 \%)$ had $R$ ratios greater than 1 in AMJ, 30 parks (8\%) had $R$ ratios greater than 1 in JAS, and 112 parks (30\%) had ratios greater than 1 in OND (Tables S2-S5).

Table 4. Summary statistics for the ratio between projected 2030 ranges (95th -5 th percentile) of departures and baseline (1981-1999) conditions in average monthly precipitation $(p)$ and runoff (R) for each season, for the 374 National Park Service parks.

\begin{tabular}{|c|c|c|c|c|}
\hline $\begin{array}{l}\text { Ratio between the Projected } \\
2030 \text { Range in Departures and } \\
\text { Baseline Conditions for }\end{array}$ & January-March & April-June & July-September & October-December \\
\hline$p, \mathrm{~mm}$-median & 0.30 & 0.28 & 0.34 & 0.33 \\
\hline$p, \mathrm{~mm}-$ maximum & 0.63 & 0.50 & 0.66 & 0.60 \\
\hline $\mathrm{R}, \mathrm{mm}-$ minimum & 0.27 & 0.22 & 0.32 & 0.31 \\
\hline
\end{tabular}

\subsubsection{Comparison of Projected Changes in Precipitation and Runoff}

A comparison of projected changes in $p$ to changes in $\mathrm{R}$ provides an indication of where future changes in hydro-climatic conditions may affect park resources. Figure 8 summarizes the output from the 214 climate simulations and indicates how many parks fall into one of four categories: (1) more than half of climate simulations projected increasing $p$ and $\mathrm{R} ;(2)$ more than half of climate simulations projected increasing $p$ and decreasing R; (3) more than half of climate simulations projected decreasing $p$ and R; and (4) more than half of climate simulations projected decreasing $p$ and increasing $\mathrm{R}$.

In JFM, the 50th percentile climate simulations projected increasing $p$ in 346 NPS parks (92.5\%) and decreasing $p$ in 28 parks (7.5\%) (Table S2). In parks with the 50th percentile climate simulations projecting increases in JFM $p$, the 50th percentile climate simulations projected increasing R in 286 parks and decreasing $\mathrm{R}$ in 60 parks (Figure 8). Parks where JFM $2030 p$ and R are both projected to increase tend to occur in the northern CONUS, whereas parks where JFM $2030 p$ is projected to increase and $\mathrm{R}$ is projected to decrease occur in the southern CONUS. In parks with the 50th percentile climate simulations projecting decreases in JFM $p$, the 50th percentile climate simulations projected decreasing $\mathrm{R}$ in 21 parks and increasing $\mathrm{R}$ in 7 parks. All parks with the 50th percentile climate simulations projecting decreases in JFM $p$ are in the southern or southwestern CONUS (Figure 8).

In AMJ, the 50th percentile climate simulations projected increasing $p$ in 276 NPS parks $(60.2 \%)$ and decreasing $p$ in 98 parks (39.8\%) (Table S3). In parks with the 50th percentile climate simulations 
projecting increases in AMJ $p$, the 50th percentile climate simulations projected increasing $\mathrm{R}$ in 51 parks and decreasing R in 225 parks (Figure 8). Parks where AMJ $2030 p$ and R are both projected to increase tend to occur along the eastern seacoast and in the north-central CONUS, whereas parks where AMJ $2030 p$ is projected to increase and $\mathrm{R}$ is projected to decrease occur broadly across the CONUS. In parks with the 50th percentile climate simulations projecting decreases in AMJ $p$, the 50th percentile climate simulations projected decreasing $\mathrm{R}$ in 83 parks and increasing $\mathrm{R}$ in 15 parks. All parks with the 50th percentile climate simulations projecting decreases in AMJ $p$ are in the western or southern CONUS (Figure 8).

(a) - JFM

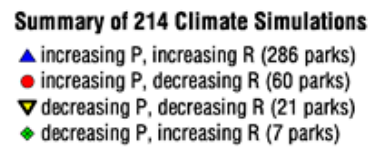

(b) - AMJ

Summary of 214 Climate Simulations $\Delta$ increasing $P$, increasing $R$ (51 parks) - increasing $\mathrm{P}$, decreasing $\mathrm{R}$ (225 parks) $\nabla$ decreasing $P$, decreasing $R$ (83 parks) - decreasing $P$, increasing $R$ (15 parks)

(c) - JAS

Summary of 214 Climate Simulations $\Delta$ increasing P, increasing R (137 parks) - increasing $P$, decreasing R (162 parks) $\boldsymbol{\nabla}$ decreasing $P$, decreasing R (72 parks) - decreasing $P$, increasing $R$ (3 parks)

(d) - OND

Summary of 214 Climate Simulations $\Delta$ increasing $P$, increasing R (163 parks) - increasing $P$, decreasing $R$ (188 parks) $\nabla$ decreasing $P$, decreasing $R$ (9 parks) $\nabla$ decreasing $P$, decreasing $R$ (9 parks)
decreasing P, increasing R (14 parks)

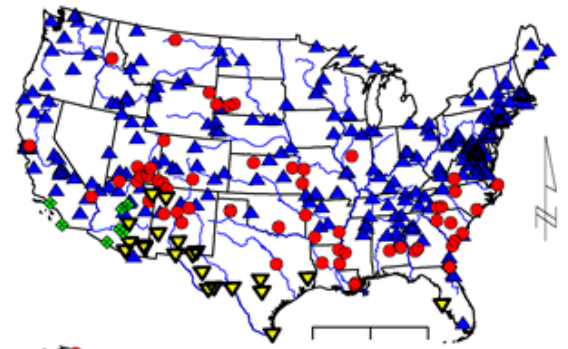

050
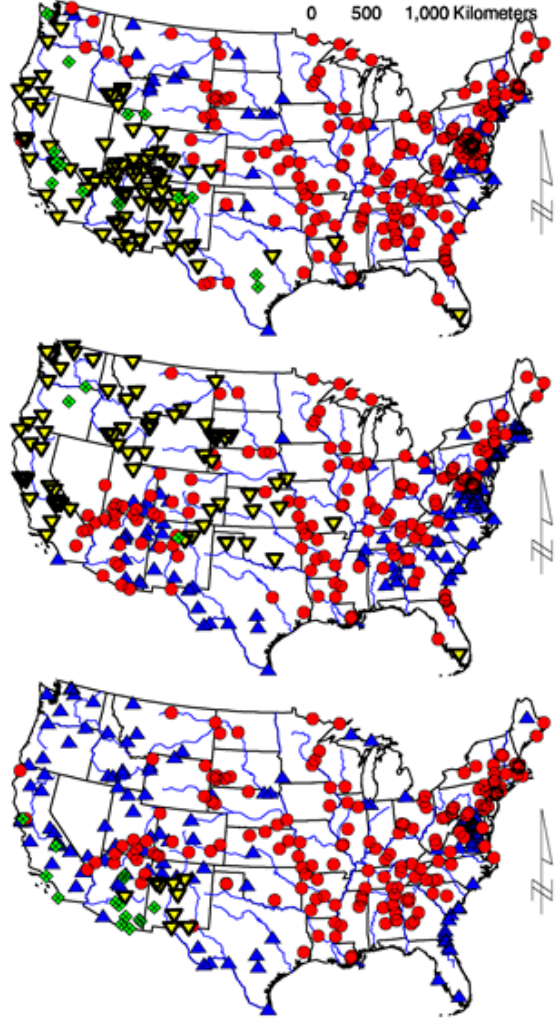

Figure 8. Summary of 214 general circulation model (GCM) climate simulations for 2030 showing where the 50th percentile projections of departures in average monthly precipitation $(p)$ and runoff $(\mathrm{R})$ are increases or decreases for each national park and the number in each category for: (a) January-March (JFM); (b) April-June (AMJ); (c) July-September (JAS); and (d) October-December (OND).

In JAS, the 50th percentile climate simulations projected increasing $p$ in 299 NPS parks (79.9\%) and decreasing $p$ in 75 parks (20.1\%) (Table S4). In parks with the 50th percentile of climate simulations projecting increases in JAS $p$, the 50th percentile climate simulations projected increasing $\mathrm{R}$ in 137 parks and decreasing R in 162 parks (Figure 8). Parks where JAS $2030 p$ and R are both projected to increase tend to occur in the eastern and southwestern CONUS, whereas parks where JAS $2030 p$ is projected to increase, and $\mathrm{R}$ is projected to decrease occur broadly across the CONUS. In parks with the 50th percentile climate simulations projecting decreases in JAS $p$, the 50th percentile climate simulations 
projected decreasing $R$ in 72 parks and increasing $R$ in 3 parks. The parks with the 50th percentile climate simulations projecting decreases in JAS $p$ are in the central and western CONUS (Figure 8).

In OND, the 50th percentile climate simulations projected increasing $p$ in 351 NPS parks (93.9\%) and decreasing $p$ in 23 parks (6.1\%) (Table S5). In parks with the 50th percentile climate simulations projecting increases in OND $p$, the 50th percentile climate simulations projected increasing $\mathrm{R}$ in 163 parks and decreasing R in 188 parks (Figure 8). Parks where OND $2030 p$ and R are both projected to increase occur broadly across the CONUS, as do parks where OND $2030 p$ is projected to increase and $\mathrm{R}$ is projected to decrease. In parks with the 50th percentile climate simulations projecting decreases in OND $p$, the 50th percentile climate simulations projected decreasing $R$ in 9 parks and increasing $R$ in 14 parks. The parks with the 50th percentile climate simulations projecting decreases in OND $p$ are in the southwestern CONUS (Figure 8).

In selected NPS parks, the seasonal interaction between $p$ and $\mathrm{T}$ and processes, such as $\mathrm{T}$ driven evapotranspiration or changes in albedo effect [40], can result in unexpected relations between changes in $p$ and changes in the magnitude and timing of R. Processes included in the MWBM, including snow accumulation and melt, soil-moisture storage, and potential evapotranspiration, can result in a variety of relations between $p$ and R. For example, more than half of the climate simulations projected $2030 p$ to increase but $\mathrm{R}$ is projected to decrease in $16 \%$ of parks in JFM, $60 \%$ of parks in AMJ, $43 \%$ of parks in JAS, and 50\% of parks in OND. When considering all parks and seasons together, the 50th percentile climate simulations project increasing $p$ and $\mathrm{R}$ in 637 park-seasons $(42.6 \%)$ (374 parks $\times 4$ seasons $=1496$ park-seasons), increases in $p$ and decreasing $R$ in 635 park-seasons $(42.4 \%)$, decreasing $p$ and $\mathrm{R}$ in 185 park-seasons (12.4\%), and decreasing $p$ and increasing $\mathrm{R}$ in 39 park-seasons $(2.6 \%)$. Hence, in many NPS parks, $\mathrm{R}$ is projected to decrease even when $p$ is projected to increase in part because of increasing $\mathrm{T}$ in all parks [25].

\section{Discussion}

\subsection{Comparison of Projected Hydro-Climatic Changes in the CONUS to Changes in National Parks}

Analysis by Gonzalez et al. [11] indicated that NPS lands in CONUS experienced statistically significant warming, while $p$ did not change significantly, over the historical period 1895-2010. Their results indicate that future $\mathrm{T}$ is projected to increase in almost all areas, rising by between 1.7 and $5.0{ }^{\circ} \mathrm{C}$ per century in CONUS and between 1.6 and $4.9{ }^{\circ} \mathrm{C}$ per century in CONUS NPS parks for the period 2000-2100. Their analysis of projections of future $p$ indicates a mixture of increases and decreases with the total land area of the CONUS showing increases between $5 \%$ and $7 \%$ per century, and the land area of parks in CONUS showing increases between $6 \%$ and $7 \%$ per century for the period 2000-2100 [11]. Those results are largely in agreement with results from this study but do not include estimates of historical or future R. Figure 9 uses boxplots to compare the projected ranges (95th percentile - 5th percentile) of departures in T, $p$, and R for 2030 from the 214 climate simulations for all HRUs in the CONUS, with only the HRUs in the 374 selected NPS parks. The projected ranges in the 2030 departures for the HRUs associated with the 374 parks are not visibly different from the projected ranges of departures for all HRUs in the CONUS (Figure 9), indicating the range of uncertainty in seasonal departures for $\mathrm{T}, p$, and $\mathrm{R}$ are similar for CONUS NPS parks and the CONUS as a whole. 


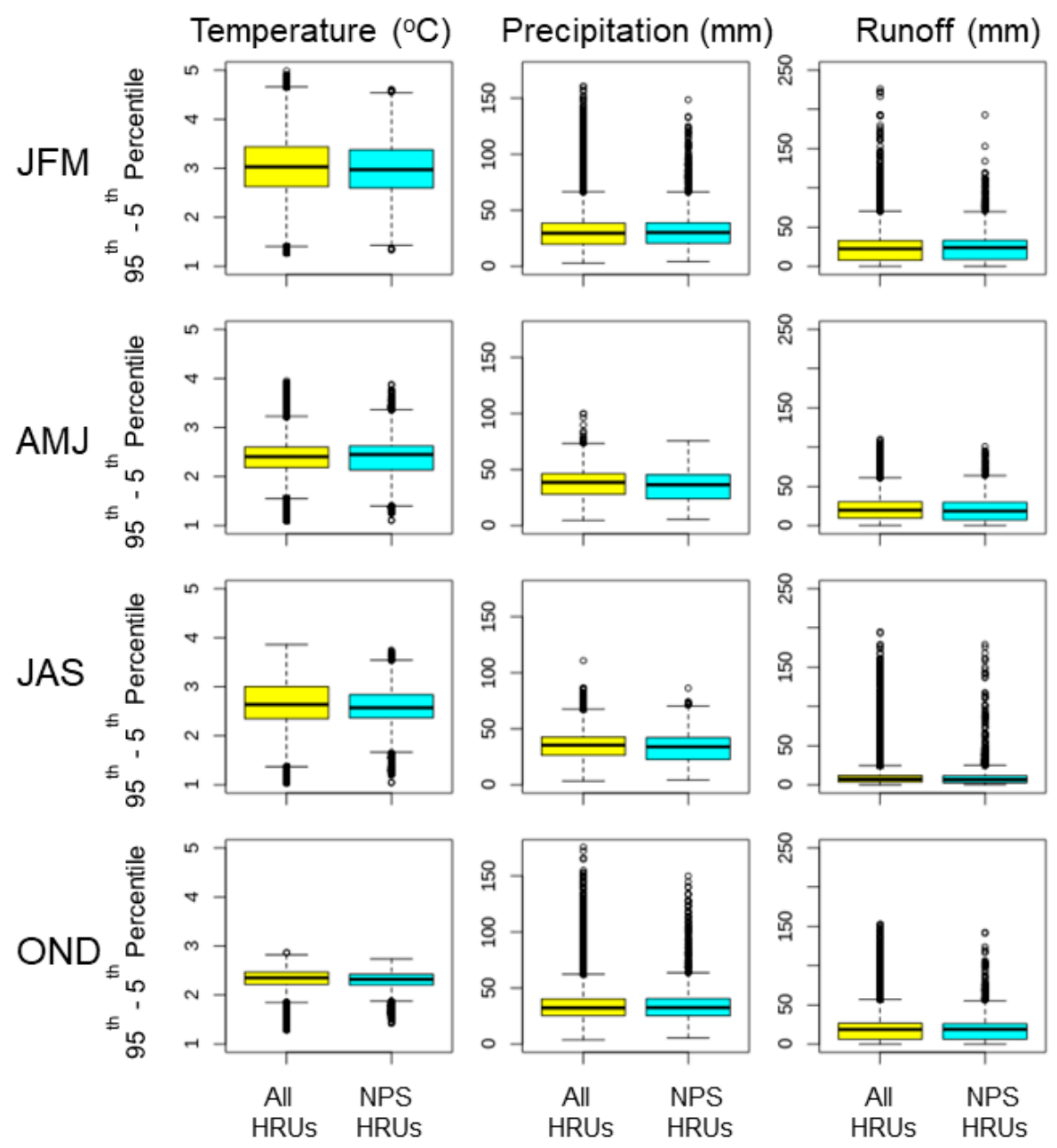

Figure 9. Boxplots comparing projected ranges (95th percentile - 5th percentile) of departures in seasonal average monthly temperature in degrees Celsius $\left({ }^{\circ} \mathrm{C}\right)$, precipitation in millimeters $(\mathrm{mm})$, and runoff in mm projected for 2030 from 214 climate simulations, for all HRUs in the CONUS (yellow) with only HRUs in national parks (NPS; cyan). HRU, Hydrologic response unit; JFM, January-March; AMJ, April-June; JAS, July-September; OND, October-December. The shaded boxes show 25th-75th percentile of projected ranges. The line across the box shows the median projected range. The whiskers extend to the largest value that is less than the 75 th percentile value plus 1.5 times the interquartile range (75th percentile-25th percentile) and to the smallest value that is greater than the 25 th percentile value minus 1.5 times the interquartile range. Outliers are shown as circles.

\subsection{Uncertainty in Projections of Temperature, Precipitation, and Runoff}

As noted above, the same projected departure in $\mathrm{T}, p$, or $\mathrm{R}$ can have substantially different effects on local hydro-climatic conditions depending on the baseline climatic conditions. Figure 10 compares baseline conditions to projected ranges (95th percentile - 5th percentile) of departures in seasonal average monthly T, $p$, and R for 2030 from the 214 climate simulations for all HRUs in the CONUS (black dots) and NPS parks in the CONUS (green dots). Additional colored dots indicate individual NPS parks that will be discussed later (ROMO and CONG). The green dots do not appear to fall as outliers in any of the plots indicating that the NPS parks in this study have ranges of uncertainty in T, $p$, and $\mathrm{R}$ that are similar to those seen for the CONUS as a whole.

A comparison of the projected ranges in $\mathrm{T}, p$, and $\mathrm{R}$ with baseline climatic conditions demonstrate a relation of increasing uncertainty with greater baseline values for $p$ and $\mathrm{R}$, but less so for T. Examining the NPS parks alone (green dots in Figure 10), there was limited correlation (Pearson's correlation) between the baseline T in NPS parks and the magnitude of the projected range in $2030 \mathrm{~T}$ departures 
by season (-0.42 in JFM, 0.16 in AMJ, 0.39 in JAS, and -0.10 in OND), and only correlations for JFM and JAS were significant at the $p<0.01$ level. These weak correlations indicate a slightly greater range in model projections of future T for NPS parks with colder baseline temperatures in JFM and slightly smaller range in model projections of future $\mathrm{T}$ in parks with colder baseline temperatures in JAS (Figure 10). The larger the range in the GCM projections in JFM and OND indicates there is increased uncertainty associated with projections in snowmelt-dominated watersheds due to larger ranges of projected cold regime temperatures.

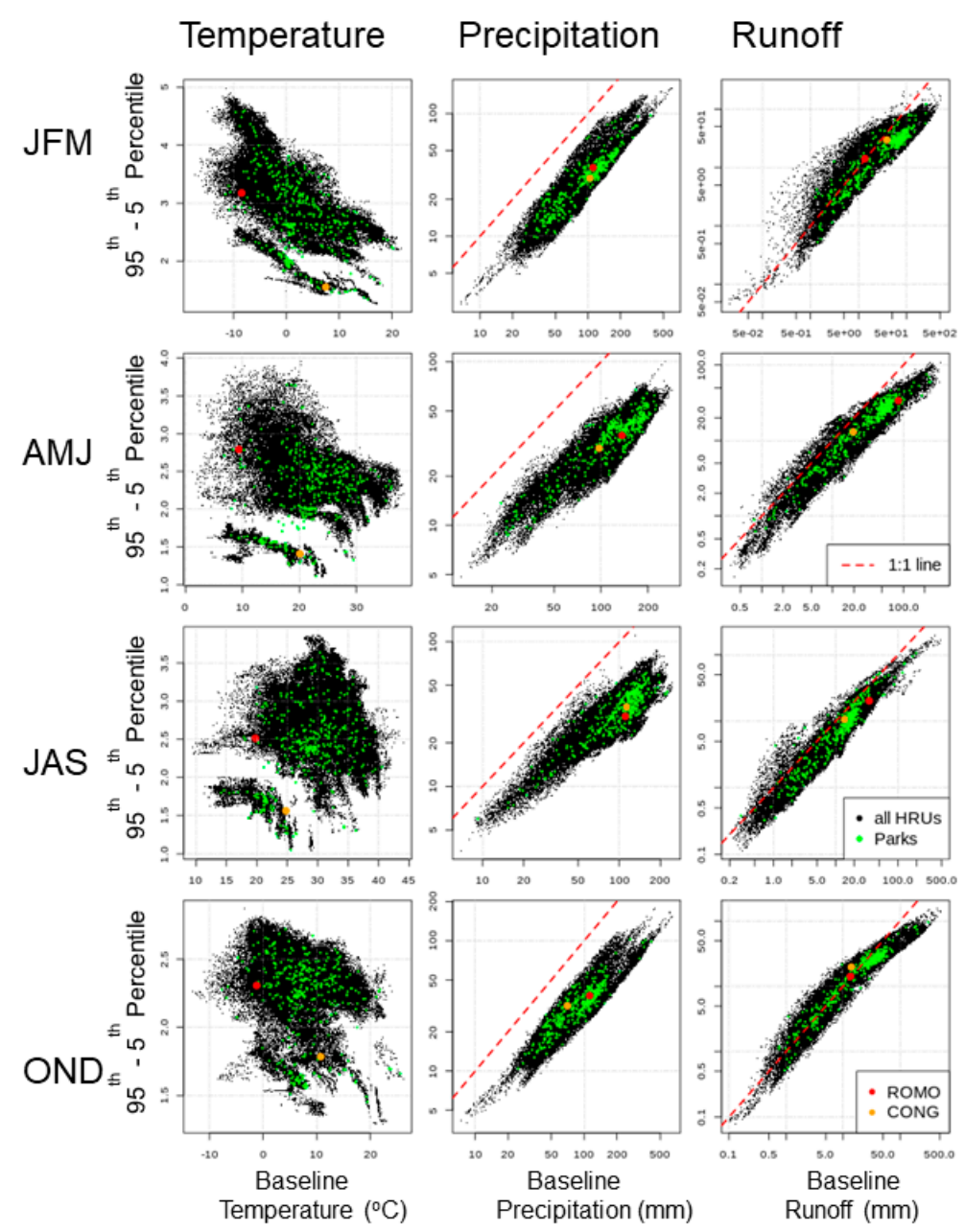

Figure 10. Comparison of baseline conditions to projected ranges (95th percentile -5 th percentile) of departures in seasonal average monthly temperature $\left({ }^{\circ} \mathrm{C}\right)$, precipitation $(\mathrm{mm})$, and runoff $(\mathrm{mm})$, projected for 2030 by 214 climate simulations, for all HRUs in the CONUS (black dots), and for national parks in the CONUS (green dots). Note that $x$-axis and $y$-axis scales can vary by season and a $\log$ scale is used on the $y$-axis for the precipitation and runoff plots. HRU, Hydrologic response unit; JFM, January-March; AMJ, April-June; JAS, July-September; OND, October-December; CONG, Congaree National Park; ROMO, Rocky Mountain National Park.

Instances where the 2030 range of projected departures approaches the magnitude of baseline conditions may indicate locations of relatively large uncertainty in future conditions. The dotted red lines on the $p$ and $\mathrm{R}$ plots in Figure 10 show where the 2030 range of projected departures would equal the baseline value. All HRU and park values for $p$ fall below this line indicating that the range in $p$ departure projections are always less than the actual baseline $p$, but the uncertainty (range) in $p$ projections increases for all seasons with increasing baseline $p$. Examining the NPS parks alone (green dots in Figure 10), there were significant positive correlations between baseline $p$ and the magnitude of projected ranges in $2030 p$ departures by season (0.91 in JFM, 0.90 in AMJ, 0.84 in JAS, 
and 0.91 in OND), and all correlations were significant at the $p<0.01$ level. These strong correlations indicate a larger range (or uncertainty) in projected future $p$ in NPS parks with larger baseline $p$ (Figure 10). In contrast to $p$, some of the HRU and park $\mathrm{R}$ values plot above the red line (Figure 10). For these locations, the range in projections of $\mathrm{R}$ departures are greater than the baseline values indicating a greater potential importance of the R changes in those parks. In NPS parks there was strong correlation between baseline $\mathrm{R}$ and the magnitude of the projected range in $2030 \mathrm{R}$ departures by season (0.90 in JFM, 0.91 in AMJ, 0.94 in JAS, and 0.91 in OND) and all correlations were significant at the $p<0.01$ level. These strong correlations indicate a larger range (or uncertainty) in projected future R departures for NPS parks with larger baseline R (Figure 10).

\subsection{Example by-Park Interpretations}

Each national park is unique, with unique susceptibilities to potential changes in climate. Providing information on potential hydro-climatic changes by NPS parks provides managers with information that can help to prioritize locations for resource conservation, an important step in the hydro-climatic change adaptation process [41]. The following sections present some interpretation of hydro-climatic changes in two example NPS parks: Rocky Mountain National Park and Congaree National Park. These two parks were selected because they represent different hydrologic conditions (headwaters versus flow-through) and hydro-climatic conditions (snowmelt dominated versus rainfall dominated).

\subsubsection{Rocky Mountain National Park}

Rocky Mountain National Park (ROMO) is a snowmelt-dominated park that includes three distinct ecosystems (montane, subalpine, alpine tundra), 147 lakes, and approximately $1076 \mathrm{~km}^{2}$ of area in north-central Colorado, USA. Much of ROMO is at high elevation, which ranges from 2396 to $4346 \mathrm{~m}$ above the National Geodetic Vertical Datum of 1929 (NGVD 29), and the Colorado, Cache la Poudre, and North Platte Rivers all headwater within ROMO. Its $\sim 200 \mathrm{~km}$ of roads and $\sim 570 \mathrm{~km}$ of trails hosted over 4.5 million visitors in 2018 [42]. All or parts of 32 HRUs fall within the boundary of ROMO. Changes in climate are projected to have substantial effects on park resources in ROMO [43].

Spatially averaged baseline $\mathrm{T}$ in $\mathrm{ROMO}$ varied substantially by season with average monthly values of about $-8.5^{\circ} \mathrm{C}$ in JFM, $9.4{ }^{\circ} \mathrm{C}$ in AMJ, $19.8{ }^{\circ} \mathrm{C}$ in JAS, and $-1.2{ }^{\circ} \mathrm{C}$ in OND (Tables S2-S5). Spatially averaged baseline $p$ in ROMO was much less variable by season with average monthly values of about $112 \mathrm{~mm}$ (JFM), $136 \mathrm{~mm}$ (AMJ), $111 \mathrm{~mm}$ (JAS), and $113 \mathrm{~mm}$ (OND). Spatially averaged baseline $\mathrm{R}$ in ROMO was more variable by season than $p$ with average monthly values of about $13.6 \mathrm{~mm}$ (JFM), $84.9 \mathrm{~mm}$ (AMJ), $34.6 \mathrm{~mm}$ (JAS), and $13.5 \mathrm{~mm}$ (OND).

The ranges of projected changes in seasonal average T, $p$, and $\mathrm{R}$ for 2030 for HRUs in ROMO by percentiles from 214 climate simulations are shown as departures from baseline conditions in Figure 11. The spread of these boxplots shows the range in projected departures for individual HRUs in ROMO. All 214 climate simulations project increases in $\mathrm{T}$ in all seasons, and there is little variability in projected departures in $\mathrm{T}$ by HRU. The 50th percentile climate simulations project $\mathrm{T}$ increases of approximately $2{ }^{\circ} \mathrm{C}$ or more in all four seasons with the largest increases projected for JAS (Figure 11).

The 50th percentile climate simulation projects increases in $p$ in 2030 in all four seasons (hence more than half of climate simulations project increases in $p$ in all HRUs). In the more extreme models (5th and 95th percentiles), there can be as much as a $10 \mathrm{~mm}$ range in the projected $p$ departures for different HRUs within ROMO, which is likely a result of the large elevation driven range in baseline $p$ amounts (Figure 11). The 2030 ratios of the projected range in $p$ departures to baseline $p$ in ROMO were less than 0.35 in all four seasons (Tables S2-S5). These ratios indicate that the uncertainty in projections of $2030 p$ are small relative to baseline $p$ values for all seasons. 

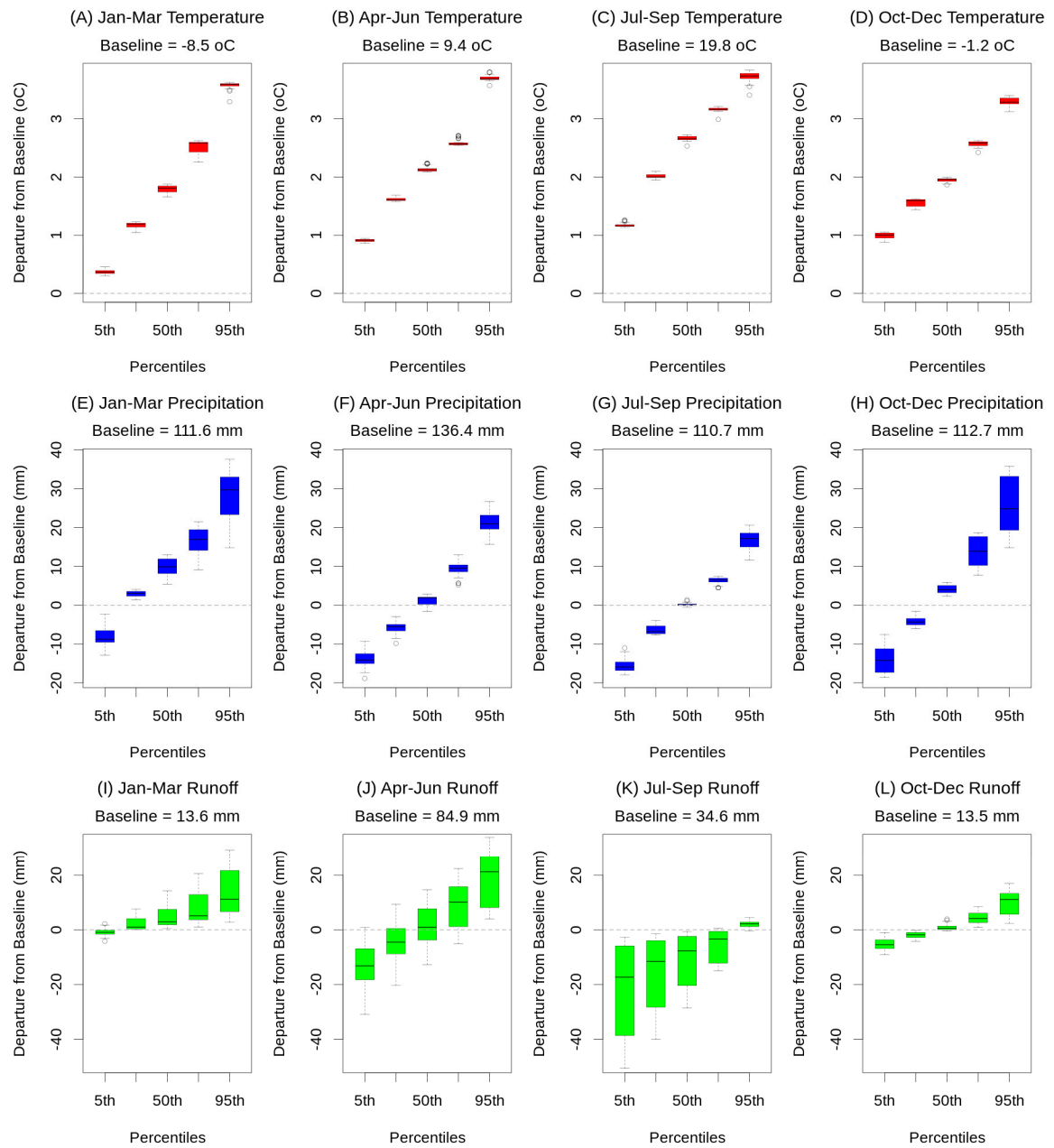

Figure 11. Boxplots showing the range of projected departures in seasonal average monthly temperature (in degrees Celsius ${ }^{\circ} \mathrm{C}$ ), precipitation in millimeters (mm), and runoff (in mm) projected for 2030 for each HRU in Rocky Mountain National Park (ROMO) by percentiles (5th, 25th, 50th, 75th, and 95th) from 214 climate simulations HRU, Hydrologic response unit; Jan-Mar, January-March; Apr-Jun, April-June; Jul-Sep, July-September; Oct-Dec, October-December. See Figure 9 caption for a full description of box and whisker statistics.

Projections of $\mathrm{R}$ for 2030 show large seasonal and within park variability. The 25th percentile climate simulations projects increases in R during JFM, whereas the 75th percentile climate simulation projects decreases in $\mathrm{R}$ during JAS (hence more than three quarters of climate simulations project decreases in all HRUs), and approximately $50 \%$ project increases in R during AMJ and OND (Figure 11). The 2030 ratios of the projected range in $R$ departures to baseline $\mathrm{R}$ in ROMO were about 1.04 in JFM, 0.40 in AMJ, 0.59 in JAS, and 1.05 in OND (Tables S2-S5). These ratios indicate that the uncertainty in projections of $2030 \mathrm{R}$ departures are as large as baseline $\mathrm{R}$ values for the JFM and OND seasons.

These projections indicate that increases in T and increases in fall and winter $p$ in ROMO may result in a temporal shift in $\mathrm{R}$ with more $\mathrm{R}$ in winter and less $\mathrm{R}$ in summer and with a large range in the model projections of $\mathrm{R}$ relative to baseline conditions in OND (fall) and JFM (winter). The wide range in projections of $p$ and R in HRUs within ROMO (Figure 11) indicate that a more detailed analysis of projected changes that accounts for elevation bands within the park is merited.

\subsubsection{Congaree National Park}

Congaree National Park (CONG) consists of old-growth forested floodplains and wetlands of international importance [44] and approximately $106.3 \mathrm{~km}^{2}$ of area in central South Carolina, USA. 
Much of CONG is at low elevation, which ranges from 24 to $43 \mathrm{~m}$ above the NGVD 29, and the Congaree River forms the southern boundary of the park. CONG had approximately 146,000 visitors in 2018 [45]. All or parts of 21 HRUs fall within the boundary of CONG.

Spatially averaged baseline $\mathrm{T}$ in CONG varies substantially by season with values of about $7.5^{\circ} \mathrm{C}$ in JFM, $20.1^{\circ} \mathrm{C}$ in AMJ, $24.8^{\circ} \mathrm{C}$ in JAS, and $10.8^{\circ} \mathrm{C}$ in OND (Tables S2-S5). Spatially averaged baseline $p$ in CONG was also variable by season with average monthly values of about $104 \mathrm{~mm}$ in JFM, $97.3 \mathrm{~mm}$ in AMJ, $113 \mathrm{~mm}$ in JAS, and $70.2 \mathrm{~mm}$ in OND. Spatially averaged baseline R in CONG was less variable by season than $p$, with average monthly values of about $38.8 \mathrm{~mm}$ in JFM, $19.5 \mathrm{~mm}$ in AMJ, $13.9 \mathrm{~mm}$ in JAS, and $14.0 \mathrm{~mm}$ in OND.

The ranges of projected changes in seasonal average monthly $\mathrm{T}, p$, and $\mathrm{R}$ for 2030 for HRUs in CONG by percentiles from 214 climate simulations are shown as departures from historical conditions in Figure 12. All models project increases in $\mathrm{T}$ in all seasons, and there is little variability in projected departures in temperature by HRU. The 50th percentile climate simulations project temperature increases of approximately $1{ }^{\circ} \mathrm{C}$ or more in all four seasons with the smallest increases projected for JFM (Figure 12). The spread of these boxplots shows the range in projected changes for individual HRUs in CONG.
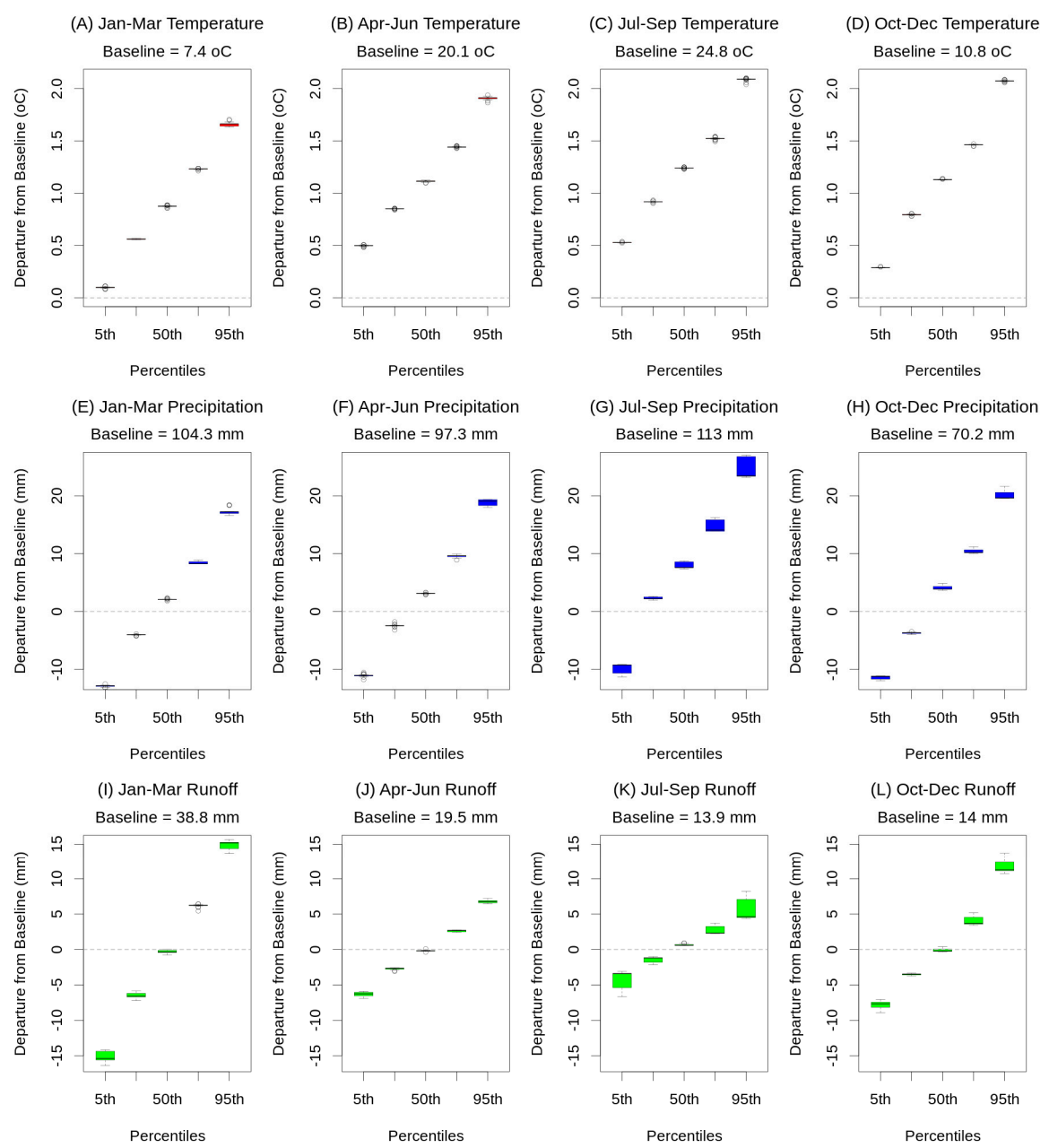

Figure 12. Boxplots showing the range of projected departures in seasonal average monthly temperature in degrees Celsius $\left({ }^{\circ} \mathrm{C}\right)$, precipitation in millimeters $(\mathrm{mm})$, and runoff (in $\mathrm{mm}$ ) projected for 2030 for each HRU in Congaree National Park (CONG) by percentiles (5th, 25th, 50th, 75th, and 95th) from 214 climate simulations HRU, Hydrologic response unit; Jan-Mar, January-March; Apr-Jun, April-June; Jul-Sep, July-September; Oct-Dec, October-December. See Figure 9 caption for a full description of box and whisker statistics. 
The 50th percentile climate simulations project increases in $p$ in all seasons (hence, more than half of the climate simulations project increases in $p$ in all seasons and all HRUs). There is not much difference in the projected departures for different HRUs within CONG which is likely a result of the lack of an elevation driven range in baseline $p$ (see interquartile range in Figure 12). The 2030 ratios of the projected range in $p$ departures to baseline $p$ in CONG were less than 0.45 in all four seasons (Tables S2-S5). These ratios indicate the uncertainty in projections of $2030 p$ are small relative to baseline $\mathrm{R}$ values for all seasons.

Projections of $R$ departures for 2030 also show little seasonal and within park variability. The 50th percentile climate simulations are near zero (approximately half of climate simulations indicate increases and half decreases in R) during all four seasons (Figure 12). The 2030 ratios of the projected range in $R$ departures to baseline $R$ in CONG were about 0.76 in JFM, 0.67 in AMJ, 0.76 in JAS, and 1.40 in OND (Tables S2-S5). These ratios indicate the uncertainty in projections of $2030 \mathrm{R}$ are moderately large and exceed baseline $\mathrm{R}$ values for the OND season.

These 2030 projections indicate that increases in T and increases in JAS $p$ in CONG may not result in a large change in $\mathrm{R}$; however, there is a large range in the model projections of $\mathrm{R}$ departures relative to baseline conditions in OND (fall). The narrow range in projections of $p$ and $\mathrm{R}$ in HRUs within CONG (Figure 12) indicate that a more detailed analysis of projected changes for individual HRUs within the park may not be merited.

\section{Conclusions}

Current and future CONUS wide projections of T, $p$, and R from an MWBM application of the NHM were analyzed to show how projections of hydro-climatic changes produced from 214 climate simulations can be interpreted for 374 NPS parks. The methodology provides decision makers with a range of plausible hydro-climatic futures to develop local adaptation strategies.

In the CONUS, $\mathrm{T}$ increased for all models in all seasons for each of the three time periods (2030, 2060, and 2090). Across most of the CONUS, the 50th percentile T departures increased to approximately $2-3^{\circ} \mathrm{C}$ in 2030 and to more than $4{ }^{\circ} \mathrm{C}$ by 2090 . In contrast to the consistently positive $\mathrm{T}$ departures, the patterns in $p$ departures indicated large uncertainty and a wide range in future $p$ projections. In 2030, 2060, and 2090, the 50th percentile $p$ departures were positive in all four seasons, which means that more than half of the climate simulations projected increases in $p$ in all seasons over most of the CONUS. Similar to patterns of departures in $p$, the $\mathrm{R}$ departure patterns indicated large uncertainty in future R projections. In 2030, 2060, and 2090 the 50th percentile R departures were negative in three of four seasons for most of the CONUS, with the exception of the JFM (winter) season, which means that more than half of the climate simulations projected decreases in R over most of the CONUS except in winter. The near future 2021-2039 period (centered on 2030) is within many NPS planning horizons and thus of priority interest. The 2030 projections indicate $\mathrm{T}$ increased for all parks with the 50th percentile climate simulations projecting increases of $1.67^{\circ} \mathrm{C}$ or more in more than half of the parks in all seasons. The 2030 projections of $p$ indicated a mix of mostly increases and some decreases in parks, with the 50th percentile climate simulations projecting increases in more than $70 \%$ of parks in all seasons. In contrast to $p$, departures in $2030 \mathrm{R}$ indicated mostly decreases with some increases, and the 50th percentile climate simulations projected decreases in more than half of the parks in all seasons except winter (January-March). Hydro-climatic processes resulting from the interaction of $\mathrm{T}$ and $p$ (e.g., snow accumulation and melt, soil-moisture storage, and potential evapotranspiration) can influence the relation between $p$ and $R$, demonstrating that $R$ trends cannot be predicted from $p$ trends alone. When considering all parks and seasons together ( 374 parks $\times 4$ seasons $=1496$ park-seasons), the 50th percentile climate simulations projected increasing $p$ and $\mathrm{R}$ in $42.6 \%$ of park-seasons, increasing in $p$ and decreasing $\mathrm{R}$ in $42.4 \%$ of park-seasons, decreasing $p$ and $\mathrm{R}$ in $12.4 \%$ of park-seasons, and decreasing $p$ and increasing $\mathrm{R}$ in $2.6 \%$ of park-seasons.

The results indicate that similar magnitude hydro-climatic changes and ranges of changes can occur in several parks, but these changes can have very different consequences locally, depending on 
baseline climatic conditions. There was strong positive correlation between baseline $p$ and $\mathrm{R}$ and the range in projections of changes in $2030 p$ and $\mathrm{R}$ indicating greater uncertainty in model projections in parks with larger baseline values of $p$ and $\mathrm{R}$.

Interpretation of results by park depends on the relative size of the HRUs associated with a park and park size. In larger parks with more topographic diversity, interpreting these results in terms of vulnerabilities for specific resources would require a finer, sub-park, analysis. In smaller parks or parks without distinct elevation gradients, whole park analyses may be appropriate. The work presented here provides each national park a range of plausible hydro-climatic futures that can be used to help assess the possible effects of future climatic conditions on park ecosystems and water dynamics related to park operations.

Supplementary Materials: The following are available online at http://www.mdpi.com/2073-4441/12/6/1704/s1, Table S1: National parks in the conterminous United States that were assessed by this study. Table S2: Baseline (1981-1999), departures from baseline by percentiles (5th, 25th, 50th, 75th, and 95th), projected range (95th percentile - 5th percentile) of departures, and the ratio of the projected range of departures to the baseline average monthly temperature in degrees Celsius $\left({ }^{\circ} \mathrm{C}\right)$ and precipitation and runoff in millimeters $(\mathrm{mm})$ for January-March (JFM) 2030 by National Park Service park. Table S3: Baseline (1981-1999), departures from baseline by percentiles (5th, 25th, 50th, 75th, and 95th), projected range (95th percentile - 5th percentile) of departures, and the ratio of the projected range of departures to the baseline average monthly temperature in degrees Celsius $\left({ }^{\circ} \mathrm{C}\right)$ and precipitation and runoff in millimeters (mm) for April-June (AMJ) 2030 by National Park Service park. Table S4: Baseline (1981-1999), departures from baseline by percentiles (5th, 25th, 50th, 75th, and 95th), projected range (95th percentile -5 th percentile) of departures, and the ratio of the projected range of departures to the baseline average monthly temperature in degrees Celsius $\left({ }^{\circ} \mathrm{C}\right)$ and precipitation and runoff in millimeters $(\mathrm{mm})$ for July-September (JAS) 2030 by National Park Service park. Table S5: Baseline (1981-1999), departures from baseline by percentiles (5th, 25th, 50th, 75th, and 95th), projected range (95th percentile - 5th percentile) of departures, and the ratio of the projected range of departures to the baseline average monthly temperature in degrees Celsius $\left({ }^{\circ} \mathrm{C}\right)$ and precipitation and runoff in millimeters (mm) for October-December (OND) 2030 by National Park Service park.

Author Contributions: Conceptualization, W.B., L.H., G.M. and D.J.L.; Methodology, W.B., L.H. and G.M.; Software, W.B., L.H. and P.N.; Validation, W.B., L.H. and D.J.L.; Formal analysis, W.B. and L.H.; Investigation, L.H. and W.B.; Resources, L.H. and D.J.L.; Data curation, L.H.; Writing-Original draft preparation, W.B., L.H., G.M. and D.J.L.; Writing—Review and editing, W.B., D.J.L. and G.M.; Visualization, L.H. and W.B.; Supervision, D.J.L.; Project administration, D.J.L. and W.B.; and Funding acquisition, D.J.L. and L.H. All authors have read and agreed to the published version of the manuscript.

Funding: This research was funded by the U.S. Geological Survey (USGS) Water Mission Area and Amphibian Research and Monitoring Initiative, and the National Park Service (NPS) Climate Change Response Program.

Acknowledgments: The authors would like to thank the many USGS personnel who provided logistical support or otherwise contributed to the creation of the data used in this study including Andy Bock, Steve Markstrom, Steve Regan, and Roland Viger. The technical support of the staff at the USGS Advanced Research Computing (ARC) group was essential in completion of this research effort. Helpful comments from Jacob LaFontaine (USGS), Alan Ellsworth (NPS), Joel Reynolds (NPS), and two anonymous reviewers greatly improved the manuscript. Any use of trade, firm, or product names is for descriptive purposes only and does not imply endorsement by the U.S. Government. This work was funded by the NPS Climate Change Response Program, the USGS Water Mission Area, and the USGS Amphibian Research and Monitoring Initiative (ARMI). Data generated during this study are available from the ScienceBase-Catalog at: https://www.sciencebase.gov/catalog/item/5bbfa10ee4b0fc368eb52c64.

Conflicts of Interest: The authors declare no conflict of interest.

\section{References}

1. National Park Service-About Us. U.S. National Park Service, U.S. Department of Interior. Available online: https://www.nps.gov/aboutus/index.htm (accessed on 2 December 2019).

2. Palmer, M.; Lettenmaier, D.P.; Poff, N.L.; Postel, S.L.; Richter, B.; Warner, R. Climate Change and River Ecosystems: Protection and Adaptation Options. Environ. Manag. 2009, 44, 1053-1068. [CrossRef] [PubMed]

3. Lawrence, D.; Runyon, A. Implications of Climate Change for the Water Supply of the Chisos Mountains Developed Area: Big Bend National Park Technical Assistance Request 4945; Natural Resource Report NPS/NRSS/CCRP/NRR—2019/2045; National Park Service: Fort Collins, CO, USA, 2019.

4. Monahan, W.B.; Fisichelli, N.A. Climate Exposure of US National Parks in a New Era of Change. PLoS ONE 2014, 9, e101302. [CrossRef] [PubMed] 
5. Tanner-McAllister, S.L.; Rhodes, J.R.; Hockings, M. Managing for climate change on protected areas: An adaptive management decision making framework. J. Environ. Manag. 2017, 204, 510-518. [CrossRef]

6. IPCC. Climate Change 1994: Radiative Forcing of Climate Change and an Evaluation of the IPCC IS92 Emission Scenarios; Houghton, J., Meira Filho, L., Bruce, J., Lee, H., Callander, B., Haites, E., Harris, N., Maskell, K., Eds.; Cambridge University Press: Cambridge, UK, 1994; 339p.

7. Dessai, S.; Hulme, M.; Lempert, R.; Pielke, R., Jr. Climate prediction: A limit to adaptation? In Adapting to Climate Change: Thresholds, Values, Governance; Adger, W., Lorenzoni, I., O’Brien, K., Eds.; Cambridge University Press: Cambridge, UK, 2009; pp. 64-78.

8. Star, J.; Rowland, E.L.; Black, M.E.; Enquist, C.A.; Garfin, G.; Hoffman, C.H.; Hartmann, H.; Jacobs, K.L.; Moss, R.-H.; Waple, A.M. Supporting adaptation decisions through scenario planning: Enabling the effective use of multiple methods. Clim. Risk Manag. 2016, 13, 88-94. [CrossRef]

9. Dawson, T.; Jackson, S.T.; House, J.; Prentice, I.C.; Mace, G.M. Beyond Predictions: Biodiversity Conservation in a Changing Climate. Science 2011, 332, 53-58. [CrossRef]

10. Markstrom, S.L.; Hay, L.E.; Clark, M.P. Towards simplification of hydrologic modeling: Identification of dominant processes. Hydrol. Earth Syst. Sci. 2016, 20, 4655-4671. [CrossRef]

11. Gonzalez, P.; Wang, F.; Notaro, M.; Vimont, D.J.; Williams, J.W. Disproportionate magnitude of climate change in United States national parks. Environ. Res. Lett. 2018, 13, 104001. [CrossRef]

12. Pringle, C. Threats to US public lands from cumulative hydrologic alterations outside of their boundaries. Ecol. Appl. 2000, 10, 971-989. [CrossRef]

13. Hay, L.E.; Clark, M.P.; Wilby, R.; Gutowski, W.J.; Leavesley, G.H.; Pan, Z.; Arritt, R.W.; Takle, E.S. Use of Regional Climate Model Output for Hydrologic Simulations. J. Hydrometeorol. 2002, 3, 571-590. [CrossRef]

14. Hay, L.E.; Lafontaine, J.; Markstrom, S.L. Evaluation of Statistically Downscaled GCM Output as Input for Hydrological and Stream Temperature Simulation in the Apalachicola-Chattahoochee-Flint River Basin (1961-99). Earth Interact. 2014, 18, 1-32. [CrossRef]

15. Bock, A.; Hay, L.; Markstrom, S.; Atkinson, R. Monthly Water Balance Model Futures (ver. 3.0, September 2018). U.S. Geol. Surv. Data Release 2018. [CrossRef]

16. Bock, A.; Hay, L.E.; McCabe, G.J.; Markstrom, S.L.; Atkinson, R.D. Do Downscaled General Circulation Models Reliably Simulate Historical Climatic Conditions? Earth Interact. 2018, 22, 1-22. [CrossRef]

17. Hay, L. A Summary of CMIP3 and CMIP5 Climate Change Projections for the Conterminous U.S. U.S. Geol. Surv. Data Release 2019. [CrossRef]

18. Maloney, K.O.; Krause, K.P.; Buchanan, C.; Hay, L.E.; McCabe, G.J.; Smith, Z.M.; Sohl, T.; Young, J.A. Disentangling the potential effects of land-use and climate change on stream conditions. Glob. Chang. Boil. 2020, 26, 2251-2269. [CrossRef]

19. Regan, R.S.; Markstrom, S.L.; Hay, L.E.; Viger, R.J.; Norton, P.A.; Driscoll, J.; Lafontaine, J.H. Description of the National Hydrologic Model for Use with the Precipitation-Runoff Modeling System (PRMS); Techniques and Methods 6-B9; U.S. Geological Survey: Reston, VA, USA, 2018; 38p. [CrossRef]

20. Regan, R.S.; Juracek, K.E.; Hay, L.E.; Markstrom, S.; Viger, R.; Driscoll, J.; Lafontaine, J.; Norton, P.A. The U.S. Geological Survey National Hydrologic Model infrastructure: Rationale, description, and application of a watershed-scale model for the conterminous United States. Environ. Model. Softw. 2019, 111, 192-203. [CrossRef]

21. National Hydrologic Model Infrastructure. U.S. Geological Survey, U.S. Department of Interior. Available online: https://www.usgs.gov/nhm (accessed on 12 December 2019).

22. Bock, A.R.; Hay, L.E.; Markstrom, S.L.; Emmerich, C.; Talbert, M. The U.S. Geological Survey Monthly Water Balance Model Futures Portal; Open-File Report 2016-1212; U.S. Geological Survey: Reston, VA, USA, 2017; 21p. [CrossRef]

23. Wolock, D.M.; McCabe, G. Explaining spatial variability in mean annual runoff in the conterminous United States. Clim. Res. 1999, 11, 149-159. [CrossRef]

24. McCabe, G.J.; Markstrom, S.L. A Monthly Water-Balance Model Driven by a Graphical User Interface; Open-File Report 2007-1088; U.S. Geological Survey: Reston, VA, USA, 2007; 6p. [CrossRef]

25. McCabe, G.J.; Wolock, D.M. Independent effects of temperature and precipitation on modeled runoff in the conterminous United States. Water Resour. Res. 2011, 47, W11522. [CrossRef]

26. Hamon, W. Estimating potential evapotranspiration. J. Hydraul. Div. Proc. Am. Soc. Civ. Eng. 1961, $87,107-120$. 
27. Bock, A.; Hay, L.E.; McCabe, G.J.; Markstrom, S.L.; Atkinson, R.D. Parameter regionalization of a monthly water balance model for the conterminous United States. Hydrol. Earth Syst. Sci. 2016, 20, 2861-2876. [CrossRef]

28. Viger, R.; Bock, A. GIS features of the geospatial fabric for national hydrologic modeling. U.S. Geol. Surv. Data Release 2014. [CrossRef]

29. Basic Information-NHDPlus (National Hydrography Dataset Plus). U.S. Environmental Protection Agency. 2019. Available online: https://www.epa.gov/waterdata/basic-information (accessed on 12 December 2019).

30. Blodgett, D.L. The U.S. Geological Survey Climate Geo Data Portal: An Integrated Broker for Climate and Geospatial Data; U.S. Geological Survey Fact Sheet 2013-3019; U.S. Geological Survey: Reston, VA, USA, 2013; 2p. [CrossRef]

31. Maurer, E.; Wood, A.; Adam, J.; Lettenmaier, D.; Nijssen, B. A Long-Term Hydrologically-Based Data Set of Land Surface Fluxes and States for the Conterminous United States. J. Clim. 2002, 15, 3237-3251. [CrossRef]

32. Wood, A.W.; Leung, L.R.; Sridhar, V.; Lettenmaier, D.P. Hydrologic Implications of Dynamical and Statistical Approaches to Downscaling Climate Model Outputs. Clim. Chang. 2004, 62, 189-216. [CrossRef]

33. Maurer, E.; Stewart, I.T.; Bonfils, C.J.W.; Duffy, P.B.; Cayan, D. Detection, attribution, and sensitivity of trends toward earlier streamflow in the Sierra Nevada. J. Geophys. Res. Space Phys. 2007, 112. [CrossRef]

34. Bureau of Reclamation. West-Wide Climate Risk Assessments: Bias-Corrected and Spatially Downscaled Surface Water Projections; Technical Memorandum No. 86-68210-2011-01, prepared by the U.S. Department of the Interior; Bureau of Reclamation, Technical Services Center: Denver, CO, USA, 2011; 138p.

35. Downscaled CMIP3 and CMIP5 Climate and Hydrology Projections: Release of Hydrology Projections, Comparison with Preceding Information, and Summary of User Needs; U.S. Department of the Interior, Bureau of Reclamation, Technical Services Center: Denver, CO, USA, 2013; 45p. Available online: https:/gdo-dcp.ucllnl.org/ downscaled_cmip_projections/dcpInterface.html (accessed on 2 November 2019).

36. IPCC. Emission Scenarios; Nakicenovic, N., Swart, R., Eds.; Cambridge University Press: Cambridge, UK, 2000; 570p.

37. Taylor, K.E.; Stouffer, R.J.; Meehl, G.A. An Overview of CMIP5 and the Experiment Design. Bull. Am. Meteorol. Soc. 2012, 93, 485-498. [CrossRef]

38. National Park Service Park Planning Catalog. U.S. National Park Service, U.S. Department of Interior. Available online: https://www.nps.gov/orgs/1804/upload/Planning_Catalog_2019_508.pdf (accessed on 12 January 2020).

39. Runyon, A.N.; Carlson, A.R.; Gross, J.; Lawrence, D.J.; Schuurman, G.W. Repeatable approaches to work with scientific uncertainty and advance climate change adaptation in US national parks. Park. Steward. Forum 2020, 36, 98-104. [CrossRef]

40. Milly, P.C.; Dunne, K.A. Colorado River flow dwindles as warming-driven loss of reflective snow energizes evaporation. Science 2020, 367, 1252-1255. [CrossRef]

41. National Park Service Climate Change Adaptation Resources. U.S. National Park Service, U.S. Department of Interior. Available online: https://www.nps.gov/subjects/climatechange/adaptationresources.htm (accessed on 5 March 2020).

42. Rocky Mountain National Park—Park Statistics. U.S. National Park Service, U.S. Department of Interior. Available online: https://www.nps.gov/romo/learn/management/statistics.htm (accessed on 7 November 2019).

43. Climate Change in Rocky Mountain National Park-Frequently Asked Questions. U.S. National Park Service, U.S. Department of Interior. 2014. Available online: https://www.nps.gov/romo/learn/nature/upload/ Climate_Change_RMNP_FAQ.pdf (accessed on 7 November 2019).

44. Ramsar Wetlands Convention. U.S. Fish and Wildlife Service, International Affairs. Available online: https://www.fws.gov/international/wildlife-without-borders/ramsar-wetlands-convention.html (accessed on 7 November 2019).

45. NPS Stats-National Park Service Visitor Use Statistics. U.S. National Park Service, U.S. Department of Interior. Available online: https:/irma.nps.gov/STATS/Reports/Park/CONG (accessed on 5 September 2019).

(C) 2020 by the authors. Licensee MDPI, Basel, Switzerland. This article is an open access article distributed under the terms and conditions of the Creative Commons Attribution (CC BY) license (http://creativecommons.org/licenses/by/4.0/). 